WITALIJ ROSOWSKI* - LUBLIN

\title{
AKTA WIZYTACYJNE DIECEZJI KAMIENIECKIEJ I ŁUCKO-ŻYTOMIERSKIEJ (KONIEC XVIII - POCZĄTEK XX WIEKU) W ZASOBACH ARCHIWÓW NA UKRAINIE
}

Rozbiory i upadek Rzeczypospolitej pod koniec XVIII wieku przyniosły również znaczące zmiany w dotychczasowej strukturze organizacyjnej i sytuacji Kościoła katolickiego na ziemiach polskich. Przed rozbiorami na interesującym nas terytorium istniały trzy diecezje: kamieniecka, kijowska i łucka. Wraz z włączeniem wschodnichziem Rzeczypospolitej do Rosji caryca Katarzyna IIukazem zdnia 6 września 1795 roku samowolnie zlikwidowała dotychczasową polską organizację kościelną na ziemiach zabranych. W zamian ustanowiono dwie nowe diecezje: pińską, do której weszły niektóre terytoria dawnej diecezji łuckiej i kijowskiej oraz latyczowską, która objęła m.in. swym terytorium dawną diecezję kamieniecką wraz z oficjałatem bracławskim z diecezji łuckiej. Stolica Apostolska nie uznała tych zmian. Taki stan rzeczy przetrwał do końca XVIII wieku, gdy po śmierci Katarzyny II na mocy ukazu cara Pawła I z 28 kwietnia 1798 roku przywrócono dawną organizację diecezjalną ${ }^{1}$. Nowe granice diecezji zostały określone dekretem delegata apostolskiego Wawrzyńca Littę z 8 sierpnia 1798 roku. Odtąd biskupstwo łuckie, połączone unią personalną z nową diecezją żytomierską powstałą w zamian kijowskiej, obejmowało gubernię wołyńską, a kamieniecka podolską. Z kolei gubernia kijowska (pod względem kościelnym archidiakonat kijowski) do połowy XIX wieku wchodziła do składu archidiecezji mohylowskiej, a następnie na mocy bulli Piusa IX Universalis Ecclesiae cura z 3 VIII 1848 roku została włączona do diecezji żytomierskiej. Warto w tym miejscu również podkreślić, że w latach 1814-1848 biskupom kamienieckim podlegało również kilka parafii znajdujących się na terytorium guberni besarabskiej. Kolejne poważne zmiany nastąpiły w 1866 roku po samowolnej kasacie diecezji kamienieckiej przez cara Aleksandra II. Od tego czasu do 1918 roku zarząd nad Kościołem

* Witalij Rosowski - dr historii; adiunkt w Ośrodku Badań nad Polonią i Duszpasterstwem Polonijnym, Wydział Humanistyczny KUL.

${ }^{1}$ Kopię ukazu zob. Державний архів Житомирської області (dalej cyt.: DAŻO), f. 178, op. 6 , spr. 15. 
rzymskokatolickim na Podolu sprawowali kolejni biskupi łucko-żytomierscy (od 1882 roku jako administratorzy apostolscy). ${ }^{2}$

Na początku XIX wieku diecezja łucko-żytomierska liczyła ponad 140 kościołów parafialnych, a kamieniecka - ponad $100^{3}$. W tym czasie na terenie wspomnianych diecezji istniało 81 klasztorów męskich i 5 żeńskich ${ }^{4}$. Represje i prześladowania władz carskich w kolejnych latach spowodowały, że liczba kościołów i klasztorów na tym obszarze zaczęła nieustannie zmniejszać się. Na przykład już w połowie XIX wieku, po włączeniu archidiakonatu kijowskiego do diecezji łucko-żytomierskiej (50 parafii), ostatnia liczyła 173 kościoły diecezjalne i zakonne, w tym na jej terenie pozostawało już 18 klasztorów męskich i 3 żeńskie 5 . Z kolei diecezja kamieniecka w tym czasie miała 115 kościołów, w tym 5 na terenie Besarabii oraz zaledwie 3 klasztory męskie i 4 żeńskie 6 . Po kolejnym pół wieku liczba świątyń katolickich na Podolu, Wołyniu i Kijowszczyźnie zmniejszyła się do 247, a jedynym czynnym konwentem pozostał klasztor bernardynów w Zasławiu?

Przedmiotem niniejszego opracowania są sprawozdania biskupów o kościołach, klasztorach i innych instytucjach diecezji kamienieckiej i łucko-żytomierskiej z końca XVIII - początku XX wieku. Akta wizytacyjne poszczególnych kościołów i klasztorów należą do jednych z najcenniejszych i najciekawszych źródeł do dziejów Kościoła rzymskokatolickiego na interesującym nas terytorium. Zawierają one bowiem wyczerpujące informacje na temat danego kościoła lub klasztoru, m.in. jego krótką historię, charakterystykę uposażenia, nieruchomości i stanu materialnego; opis świątyni i jej zawartości, biblioteki, a w wypadku klasztorów także stan personalny wspólnoty zakonnej. Biskup był zobowiązany osobiście lub poprzez wyznaczonego wizytatora każdego roku odbywać wizytację i wysyłać sprawozdanie do Kolegium Duchownego w Petersburgu. Wizytacje sporządzał najczęściej miejscowy dziekan lub przełożony danego zakonu w porozumieniu z proboszczem lub przeorem. Zazwyczaj przygotowywano kilka kopii - jedną, jak już wspomniano, wysyłano do Petersburga, druga trafiała do archiwum kurii biskupiej, a pozostałe były przechowywane w archiwum miejscowego dziekana, parafii lub klasztoru.

W dotychczasowej historiografii jedyną publikacją częściowo obejmującą przedstawiany temat pozostaje praca księdza Mariana Radwana, poświęcona wizytacjom znajdującym się w dawnym Archiwum Petersburskiego Kolegium Du-

${ }^{2}$ Zob. B. Kumor, Granice metropolii i diecezji polskich 968-1939, „Archiwa, Biblioteki i Muzea Kościelne”, 20 (1970) s. 291-292, 294-297.

${ }^{3}$ Directorium officii divini ac missarum ad usum Dioecesis Luceoriensis Pro Anno Domini MDCCCII, Luceoriae [1801]; Kumor, Granice metropolii, s. 292, 297.

${ }^{4}$ Kumor, Granice metropolii, s. 292, 297; M. Radwan, Zakony męskie na ziemiach zabranych $w$ XIX wieku, Lublin 2004, s. 10-11, 15; tenże, Antyzakonna polityka caratu w XIX wieku, „Studia Catholica Podoliae", 1 (2002) nr 1, s. 160-161, 163.

${ }^{5}$ Por. Directorium officii divini ac missarum ad usum Dioecesis Luceoriensis Pro Anno Domini MDCCCL, Vilnae 1849.

${ }^{6}$ Directorium officii divini Dioecesis Camenecensis ac ecclesiarum in Bessarabia In Annum Domini 1849, Vilnae 1848.

${ }^{7}$ Kalendarium liturgicum dioecesium Luceoriensis et Żytomiriensis, nec non ecclesiarum per Podoliam, Anno Domini 1901, Żytomiriae 1900, s. 71-72. 
chownego (obecnie w Rosyjskim Państwowym Archiwum Historycznym w Pe-

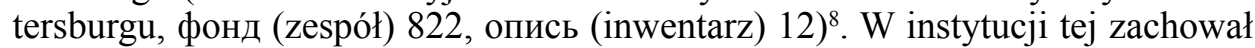
się największy i najbardziej kompletny zbiór interesujących nas akt wizytacyjnych z lat 1797-19149. Dla przykładu warto podać, że wspomniany inwentarz obejmuje ponad 2600 jednostek archiwalnych (odnoszących się zarówno do pojedynczych kościołów, jak i całej diecezji) dotyczących diecezji kamienieckiej i łucko-żytomierskiej. Do tego należy dodać wizytacje parafii i klasztorów z archidiakonatu kijowskiego, który do połowy XIX w. znajdował się w granicach archidiecezji mohylowskiej ${ }^{10}$. Mimo tak dużego zasobu część tych archiwaliów, jak zaznaczył ks. M. Radwan, została bezpowrotnie utracona ${ }^{11}$. Największe luki dotyczą lat 1802-1819, 1864-1876 lub 1881-1909. Część brakujących w Petersburgu materiałów można odnaleźć w archiwach państwowych na Ukrainie.

Burzliwe losy tych ziem w ciągu ostatniego stulecia spowodowały, że część archiwaliów diecezji kamienieckiej i łucko-żytomierskiej, które po rewolucji 1917 roku zostały skonfiskowane i przekazane do archiwów państwowych, uległa zniszczeniu, a reszta została rozproszona. Obecnie różnego rodzaju zespoły archiwalne poświęcone Kościołowi katolickiemu na terytorium dawnego Generał-gubernatorstwa Kijowskiego, Podolskiego i Wołyńskiego przechowywane są w jedenastu archiwach państwowych na Ukrainie. Są to: Centralne Państwowe Historyczne Archiwum w Kijowie (Центральний державний історичний архів України в Києві, dalej суt. CDIAU Kijów), Państwowe Archiwum miasta Kijowa (Державний архів міста Києва, DAK) oraz Państwowe Archiwa Obwodowe w Kijowie (Державний архів Київської області, DAKijO), Chmielnickim (Державний архів Хмельницької області, DAChO), Czerkasach (Державний архів Черкаської області, DACzO), Kirowogradzie (Державний архів Кіровоградської області, DAKirO), Łucku (Державний архів Волинської області, DAWO), Odessie (Державний архів Одеської області, DAOO), Równym (Державний архів Рівненської області, DARO), Winnicy (Державний архів Вінницької області, DAWinO) czy Żytomierzu (Державний архів Житомирської області, DAŻO). W części wymienionych archiwów istnieją zespoły poświęcone wybranym rzymskokatolickim kościołom lub dekanatom, zawierające przeważnie akta metrykalne (np. DACzO: fond 363 (dekanat Zwinogródzki), f. 385 (kościół Moszny) i f. 421 (kościół Smiła); DAKijO: f. 1574 (kościół Motowidłówka); DAKirO: f. 728 (kościół Złatopol); DAOO: f. 921 (kościół Bałta); DARO: f. 249 (dekanat Krzemieniecki); DAWO: f. 22 (dekanat Łucki), f. 193 (Włodzimierski) i f. 195 (Kowelski); DAWinO: f. 409 (kościół Pików), f. 653 (Ułanów), f. 737 (Kolekcja dokumentów katolickich dekanatów Kijowskiej i Podolskiej guberni), f. 711 (dekanat Lityński), f. 712 (Jampolski), f. 741 (kościół Białopol), f. 802 (Bracław), f. 803 (Winnica).

${ }^{8}$ Zob. M. Radwan, Repertorium wizytacji kościołów i klasztorów w Archiwum Petersburskiego Kolegium Duchownego (1797-1914), Lublin 1998.

${ }^{9}$ Tamże, s. 11-29, 65-76.

${ }^{10}$ Patrz: Tamże, s. 33-61. Są tu wizytacje kościołów z około 50 miejscowości, w tym również 26 klasztorów, 3 seminariów duchownych i jednego szpitala parafialnego.

${ }^{11}$ Por. Tamże, s. 7. 
Najwięcej materiałów archiwalnych po dawnych diecezjach kamienieckiej i łucko-żytomierskiej zachowało się w trzech ukraińskich archiwach: Centralnym Państwowym Historycznym Archiwum Ukrainy w Kijowie oraz archiwach obwodowych w Chmielnickim i Żytomierzu. Szczególnie ważne są dwa ostatnie archiwa, w których zgromadzono główny trzon zachowanych do dziś dokumentów archiwalnych wytworzonych przez kamieniecką i lucko-żytomierską kurię biskupią. Większość interesujących nas akt wizytacyjnych znajduje się właśnie w zasobach tych archiwów. Warto w tym miejscu podkreślić, że osobnego repertorium archiwaliów kościelnych doczekały się jedynie zespoły przechowywane $\mathrm{w}$ archiwum żytomierskim ${ }^{12}$. Publikacja ta obejmuje najważniejsze zespoły archiwaliów wytworzonych w instytucjach kościelnych przechowywane obecnie w Żytomierzu. Pominięto w nim jednak dwa niewielkie, choć istotne dla nas zespoły: nr 401 „Wice-dziekana Katedry Żytomierskiej” i 402 „Dziekana Powiatu Żytomierskiego". W wprowadzeniu do repertorium autor zwrócił celną uwagę na fakt, że większość zgromadzonych materiałów w tym archiwum inwentaryzowały osoby nie mające pojęcia o życiu kościelnym ${ }^{13}$. Reguła ta sprawdza się praktycznie w każdym z wspomnianych wyżej archiwów na Ukrainie, gdzie znalazły się archiwalia proweniencji kościelnej.

Najstarsze z zachowanych wizytacji kościołów i klasztorów rzymskokatolickich na Podolu, Wołyniu i Kijowszczyźnie z okresu zaborów sięgają czasu istnienia na tych ziemiach diecezji pińskiej i latyczowskiej. Ordynariuszem pierwszej został dawny koadiutor kijowski biskup Kasper Cieciszowski, a drugiej-Michał Sierakowski. Ostatni, informując Senat o powołaniu 31 marca 1796 roku konsystorza diecezji latyczowskiej zaznaczył, że „Kościoły i Klasztory w Moiey Eparchij będące Wizytować zacząłem i już Kilka iadąc do Kamieńca na Otwarcie Gubernii zwizytowałem a po Otwarciu Gubernii, po za Dubno Krzemieniec zacząwszy wciąż dokończę abym jaknaydokładnieysze Opisanie Wszystkich Kosciołow i Klasztorow przesłał Rządzącemu Senatowi" ${ }^{14}$. Podobnie też uczynił biskup diecezji pińskiej i zaczął wizytacje podległych swojej jurysdykcji kościołów i klasztorów. Najwięcej wizytacji z tego okresu zachowało się w zasobach CDIAU w Kijowie w zespole nr 2227 „Kolekcja Dokumentów Muzeum Wołyńskiego” (np. sprawa 649 - Protokoły wizytacji generalnej kościołów i klasztorów okregu Wtodzimierskiego (k. 83) oraz spr. 651 - dekanatu Kowelskiego (k. 197). Ponadto w zespołach nr 1044 (dekanat Żytomierski), 1045 (dekanat Rówieński i Nowograd-Wołyński) i 1046 (dekanat Lipowiec-Berdyczowski) są wizytacje $\mathrm{z}$ tego okresu kościoła pw. św. Barbary w Berdyczowie i klasztoru bernardyńskiego w Cudnowie oraz inwentarze kościołów w Równym i Ostrogu. W DAŻO natomiast w zespole nr 90 pt. „Wizytator klasztorów rzymskokatolickich diecezji Łucko-Żytomierskiej" są wizytacje powiatu łuckiego (opis 1, spr. 200). Poza tym pojedyncze wizytacje z lat 1796 i 1797 kościołów w Ostrogu i Złoczówce, dek. Dubno (spr. 200a) czy klasztorów ojców bonifratrów i sióstr brygidek w Łucku (spr. 213b, k. 436-462). Wyjątkiem jest również teczka zespołu nr 178 ,Łucko-Żytomierski

\footnotetext{
${ }^{12}$ Zob. M. Radwan, Archiwa diecezji Łucko-Żytomierskiej. Repertorium, Lublin 2003.

${ }^{13}$ Tamże, s. 5.

${ }^{14}$ DAŻO, f. 178, op. 4, spr. 1, k. 27.
} 
Konsystorz Rzymskokatolicki”, gdzie są wizytacje różnych kościołów diecezji łuckiej z 1795 roku (op. 51, spr. 3). Pojedyncze wizytacje z tego okresu zachowały się również w zasobach archiwum w Chmielnickim (np. kościoły parafialne Mańkowce i Płoskirow (1796) oraz Granów (1797) ${ }^{15}$.

W porównaniu do późniejszego okresu (po 1798), gdy oficjalnie została ustanowiona i zatwierdzona przez Stolicę Apostolską organizacja terytorialna Kościoła rzymskokatolickiego na ziemiach zabranych pod zaborem rosyjskim, zachowało się jednak bardzo niewiele opisów wizytacyjnych. Dopiero od 1799 roku kolejni biskupi rezydujący w Kamieńcu Podolskim i Łucku (a od 1844 roku w Żytomierzu) regularne zaczęli wizytować swoje diecezje. Najwięcej akt wizytacyjnych dotrwało do naszego czasu właśnie z lat 1799-1850. Praktycznie do połowy XIX wieku były one sporządzane w języku polskim i dopiero w późniejszych latach redagowano je w języku rosyjskim. Należy też zaznaczyć, że do połowy XIX wieku wizytacje biskupie sporządzono niemalże każdego roku. Natomiast poczynając od 1851 roku, aż do wybuchu I wojny światowej dziekani lub proboszczowie przygotowywali wizytacje za okres pięcioletni (np. 1851-1856, 1856-1861 itd.).

Na Ukrainie najbogatsze zbiory interesujących nas akt posiada Państwowe Archiwum Obwodu Żytomierskiego (DAŻO). Ogółem znajduje się tam około 1250 poszytów (jednostek archiwalnych) zawierających wizytacje poszczególnych kościołów i klasztorów tak diecezji łucko-żytomierskiej, jak kamienieckiej. Najwcześniejsze wizytacje sięgają lat 1795-1796, a najpóźniejsze - lat 1904-1909. Warto zaznaczyć, że ponad $60 \%$ zachowanych tu opisów dotyczy okresu 1816-1833. Zdecydowana większość tych materiałów (ponad 1160 poszytów z lat 1796-1904) znajduje się w zespole Wizytatora $\mathrm{nr}$ 90, a reszta - wśród dokumentów zespołu Konsystorza nr 178 (lata 1795-1909) i zespołu Dekanatu żytomierskiego nr 402 (są to dwie wizytacje dziekańskie za pięciolecie 1856-1861 i 18761881). Przeważnie są to wizytacje parafii i klasztorów z terenu diecezji łucko-żytomierskiej, jednak są również sporadyczne akta $\mathrm{z}$ diecezji kamienieckiej (np. dekanatu płoskirowskiego z 1888 roku lub katedry w Kamieńcu Podolski i kościołów w Latyczowie, Sokólcu, Tynnie czy Winnicy).

Warto także zauważyć, że wśród wymienionych zespołów DAŻO niejednokrotnie napotkać można na akta wizytacyjne Kościoła unickiego: np. klasztoru bazylianów w Tryhorach (f. 90, op. 1, spr. 526, 1030; op. 2 spr. 8) czy Owruczu (f. 90, op. 1 spr. 281 i 281a); cerkwi Minhowieckiej w powiecie dubieńskim (f. 90, op. 1 spr. 336, k. 36-37, z 1783 roku). Z dużą rezerwą należy również traktować niektóre zbyt ogólnikowe i niedokładne opisy w inwentarzu zespołów 90 i 178. Między innymi poszyty zatytułowane Opisy wizytacyjne kościołów i klasztorów guberni Wotyńskiej (lub diecezji Łucko-Zytomierskiej) często zawierały materiały zupełnie innej treści (np. informacje o rachunkach i annuatach lub raporty z wykonania zaleceń powizytacyjnych lub zbiór różnych dokumentów i korespondencji z poszczególnych kościołów) ${ }^{16}$. Dla odmiany w innych teczkach zamiast wizy-

\footnotetext{
${ }^{15}$ Patrz aneks.

${ }^{16}$ Patrz: DAŻO, f. 90, op. 1, spr. 230, 253, 254, 278.
} 
tacji całej diecezji były akta tylko jednego dekanatu ${ }^{17}$ lub opisy wybranych klasztorów ${ }^{18}$.

O stanie zachowania prezentowanych archiwaliów świadczy sprawozdanie archiwisty konsystorza łucko-żytomierskiego przedstawiające wykaz opisów wizytacyjnych przekazanych do tego archiwum za okres 1850-1881. Dokument ten wykazał, że za wyjątkiem lat 1851-1861 do archiwum konsystorza wpłynęło ogółem 475 egzemplarzy wizytacji poszczególnych dekanatów, kościołów i klasztorów wspomnianych diecezji ${ }^{19}$. Według obliczeń autora obecnie ich liczba nie przekracza 200 poszytów.

Znacznie skromniejszymi zasobami aktów wizytacyjnych może pochwalić się archiwum w Chmielnickim (DAChO). Zgromadzono tu archiwalia diecezji kamienieckiej poczynając od końca XVIII wieku do kasaty w 1866 roku. Podobnie jak w archiwum żytomierskim są to głównie dwa zespoły: „Kamieniecki Konsystorz Rzymskokatolicki” (nr 685) oraz „Wizytator klasztorów diecezji Kamienieckiej" (nr 689). Wśród dokumentów ostatniego zespołu zachowało się jedynie dwie wizytacje klasztoru dominikanów w Murafie i sióstr wizytek w Kamieńcu Podolskim. Reszta 26 poszytów z zespołu nr 685 obejmuje najczęściej obszar całej diecezji (lata 1823-1862). Niektóre z nich są bardzo obszerne (np. op. 2, spr. 4 (k. 470), 22 (k. 753), 58 (k. 637), 133 (k. 731). Kilka poszytów z opisu 4 poświęconych jest wyłącznie wizytacjom zakonów i klasztorów działających na Podolu (np. spr. 21-23 i 30). Do wyjątków należą natomiast teczki z wizytacjami pojedynczych kościołów (m.in. Bałta, Jampol, Płoskirów). Uzupełnieniem do archiwaliów diecezji kamienieckiej są wizytacje sześciu bernardyńskich i kapucyńskich klasztorów z Podola znajdujące się w archiwum w Winnicy (F. 737, pt. Kolekcja dokumentów katolickich dekanatów Kijowskiej i Podolskiej guberni, op. 1, spr. 3 (lata 1799-1820). Wspomniane akta, wraz z kolekcją ksiąg metrykalnych $\mathrm{z}$ parafii dawnego archidiakonatu kijowskiego, zostały po wojnie przekazane do Winnicy $\mathrm{z}$ archiwum żytomierskiego.

Ponadto około 60 poszytów akt wizytacyjnych, w większości dotyczących pojedynczych kościołów i klasztorów znajdujących się na obszarze guberni kijowskiej (lata 1796-1881), zachowały się w zasobach CDIAU w Kijowie. Skupiają się one we wspomnianym już zespole nr 2227 (Kolekcja Dokumentów Muzeum Wolyńskiego) oraz zespołach niektórych dekanatów rzymskokatolickich: Radomyślskiego (zespół nr 1040), Skwirskiego (1041), Żytomierskiego (1044), Równeńskiego i Nowogród-Wołyńskiego (1045) oraz Lipowiec-Berdyczowskiego (1046). W poszukiwaniach interesujących nas wizytacji przechowywanych w zasobach archiwów na Ukrainie nie należy też ograniczać się wyłącznie do zespołów związanych z Kościołem rzymskokatolickim. Pokazuje to dokładnie przykład z Łucka i Równego. Na przykład w zespole „Prawosławnego Wołyńskiego Du-

${ }^{17}$ Np. dekanatu żytomierskiego. Zob. DAŻO, f. 178, op. 2, spr. 1068.

${ }^{18}$ DAŻO, f. 90, op. 1, spr. 1213a i 213b. O ile pierwsza sprawa obejmuje wyłącznie klasztory karmelitańskie z lat 1799-1805, to druga - różnych zakonów na terenie gubernii wołyńskiej.

${ }^{19}$ Por. DAŻO, f. 178 , op. 7 , spr. 1258, k. 1-16. 
chownego Konsystorza" (nr 35) w DAWO udało się odnaleźć kopię Księgi wizyt Sokulskiego Rzymskokatolickiego Kościoła z 1918 roku $^{20}$. Natomiast w archiwum obwodowym w Równym w zespole barona F. Steinheila (DARO, F. 366), powinny znajdować się wizytacje niektórych kościołów i klasztorów na Wołyniu (np. Derażne).

Przedstawiony poniżej załącznik wykazał, że w zasobach archiwalnych na Ukrainie do dziś zachowało się ogółem około 1350 jednostek archiwalnych (poszytów) akt wizytacyjnych kościołów i klasztorów z terenów diecezji kamienieckiej i łucko-żytomierskiej. Głównie dotyczą one okresu 1799-1909, choć spotykają się również nieliczne wizytacje $\mathrm{z}$ lat 90 -tych XVIII wieku. Zdecydowana większość tych teczek (1226) dotyczy pojedynczych kościołów lub klasztorów. W tej części wykazu wymieniono akta wizytacyjne 130 kościołów parafialnych oraz 71 klasztorów męskich i 6 żeńskich. Reszta materiałów obejmuje całość lub części interesujących nas diecezji oraz poszczególne dekanaty. Warto zauważyć, że jest to pierwszy tego rodzaju wykaz, który ma za zadanie pomóc badaczom zajmującym się dziejami Kościoła rzymskokatolickiego na Podolu, Wołyniu i Kijowszczyźnie w dotarciu do rozproszonych źródeł. Należy mieć nadzieję, że dalsze prace pozwolą na bardziej dokładne zweryfikowanie i uzupełnienie zamieszczonego tu spisu.

\section{ANEKS}

Wykaz akt wizytacyjnych kościołów i klasztorów diecezji kamienieckiej i lucko-żytomierskiej z końca XVIII - początku XX w. przechowywanych w państwowych zasobach archiwalnych na Ukrainie

\begin{tabular}{|c|c|c|c|c|}
\hline $\mathrm{Nr}$ & Diecezja/gubernia & Lata & Archiwum & $\begin{array}{c}\text { Sygnatura } \\
\text { Fond/opis/sprawa }\end{array}$ \\
\hline \multirow{9}{*}{1.} & \multirow{9}{*}{$\begin{array}{l}\text { Kamieniecka diec.: } \\
\text { [są też wizytacje kościołów z Besara- } \\
\text { bii: Chocim, Kiszyniów, Krasne] }\end{array}$} & $\begin{array}{l}1825 \\
1826 \\
1827\end{array}$ & DAChO & $\begin{array}{l}\text { F. } 685 \text {, op. } 2 \text {, spr. } 2 \\
\text { spr. } 3 \\
\text { spr. } 4\end{array}$ \\
\hline & & 1844-1849 & DAChO & F. 685 , op. 2, spr. 23 \\
\hline & & 1844 & DAChO & F. 685 , op. 2 , spr. 22 \\
\hline & & $\begin{array}{l}1846 \\
1847 \\
1848\end{array}$ & DAChO & $\begin{array}{l}\text { F. } 685 \text {, op. } 2 \text {, spr. } 34 \\
\text { spr. } 41 \\
\text { spr. } 48\end{array}$ \\
\hline & & 1850 & DAChO & F. 685 , op. 2, spr. 58 \\
\hline & & $\begin{array}{l}1852 \\
1853 \\
1854 \\
1855\end{array}$ & DAChO & $\begin{array}{l}\text { F. } 685 \text {, op. 2, spr. 73; } \\
\text { spr. 78; } \\
\text { spr. 83; } \\
\text { spr. } 90\end{array}$ \\
\hline & & 1857 & DAChO & $\begin{array}{l}\text { F. } 685 \text {, op. } 2 \text {, spr. } 102 ; \\
\text { spr. } 103\end{array}$ \\
\hline & & 1858 & DAChO & F. 685 , op. 2 , spr. 110 \\
\hline & & 1862 & DAChO & F. 685, op. 2, spr. 133 \\
\hline
\end{tabular}

${ }^{20}$ Parz DAWO, f. 35 , op. 1, spr. 468, k. 1-2. 


\begin{tabular}{|c|c|c|c|c|}
\hline \multirow{14}{*}{2.} & $\begin{array}{l}\text { Łucka i Żytomierska diec., [opisanie } \\
\text { różnych kościołów] }\end{array}$ & 1795(1796) & DAŻO & F. 178 , op. 51 , spr. 3 \\
\hline & [Cała diec.: kościoły parafialne] & $1796-1816$ & DAŻO & F. 90 , op. 1 , spr. $200 \mathrm{a}$ \\
\hline & $\begin{array}{l}\text { [Różne kościoły i klasztory m.in. } \\
\text { Krasnesioło, Ostróg, Zasław, Stary } \\
\text { Konstantynów] }\end{array}$ & 1799 & DAŻO & F. 178 , op. 51 , spr. 11 \\
\hline & \multirow{4}{*}{ Łucka i Żytomierska diec.: } & 1799 & DAŻO & F. 178 , op. 51 , spr. 8 \\
\hline & & 1800 & DAŻO & F. 178 , op. 4 , spr. 17 \\
\hline & & 1801 & DAŻO & F. 90 , op. 1, spr. 232 \\
\hline & & 1802 & DAŻO & F. 90, op. 2, spr. 2 \\
\hline & $\begin{array}{l}\text { [Dekanaty: Zasław, Łuck, Kowel, St. } \\
\text { Konstantynów] }\end{array}$ & 1803 & DAŻO & F. 90 , op. 2 , spr. 3 \\
\hline & \multirow{6}{*}{ Łucka i Żytomierska diec. } & 1806 & DAŻO & F. 178 , op. 4 , spr. 36 \\
\hline & & 1807 & DAŻO & F. 90, op. 2, spr. 7 \\
\hline & & 1839 & DAŻO & F. 178 , op. 4 , spr. 247 \\
\hline & & 1845 & DAŻO & F. 178 , op. 51 , spr. 79 \\
\hline & & $1851-[1856]$ & DAŻO & F. 178 , op. 7 , spr. 853 \\
\hline & & $1851-1856$ & DAŻO & F. 178 , op. 7 , spr. 1612 \\
\hline \multirow[t]{3}{*}{3.} & $\begin{array}{l}\text { Wołyńska gub.: } \\
\text { [m. in. dekanaty: Kowel, Łuck i Wło- } \\
\text { dzimierz Wołyński] } \\
\text { [m.in. dekanaty: Nowogród Wołyński, } \\
\text { Owrucz i Żytomierz] }\end{array}$ & 1799 & DAŻO & $\begin{array}{l}\text { F. } 178 \text {, op. } 51 \text {, spr. } 6 \text {; } \\
\text { F. } 178 \text {, op. } 51 \text {, spr. } 7\end{array}$ \\
\hline & Wołyńska gub. & $1802-1804$ & DAŻO & F. 178 , op. 51 , spr. 14 \\
\hline & $\begin{array}{l}\text { [Różne kościoły i klasztory m.in. De- } \\
\text { rażne, dek. Równe] }\end{array}$ & XIX w. & DARO, Równe & $\begin{array}{l}\text { F. 366, op. } 1 \\
\text { (zespół barona F. Steinheil) }\end{array}$ \\
\hline & Ogólem: & 1795-1862 & \multicolumn{2}{|r|}{35 poszytów } \\
\hline & Dekanat/powiat & Lata & Archiwum & Sygnatura \\
\hline 1. & Bracław & $1799-1826$ & DAChO & F. 685 , op. 4 , spr. 7 \\
\hline \multirow{7}{*}{2.} & \multirow{7}{*}{ Dubno } & 1798 & DAŻO & F. 178 , op. 51 , spr. 4 \\
\hline & & 1817 & DAŻO & F. 90, op. 1, spr. 299 \\
\hline & & 1876 & DAŻO & F. 90 , op. 1, spr. 1282 \\
\hline & & 1881 & DAŻO & F. 90, op. 1, spr. 1301 \\
\hline & & 1881 & DAŻO & F. 90, op. 1, spr. 1304 \\
\hline & & 1881 & DAŻO & F. 90, op. 1, spr. 1305 \\
\hline & & 1889 & DAŻO & F. 90 , op. 1, spr. 1333 \\
\hline 3. & Kamieniec Podolski & 1830 & DAChO & F. 685 , op. 4 , spr. 31 \\
\hline 4. & Kijów-Wasylków & XIX w. & DAK m. Kijów & F. 312 , op. 1 \\
\hline \multirow{4}{*}{5.} & \multirow{4}{*}{$\begin{array}{l}\text { Kowel [Buceń, Kamień-Koszyrski, } \\
\text { Kowel, Maciejów, Nabrzuska, Ratno, } \\
\text { Turzysk] }\end{array}$} & 1796 & CDIAU, Kijów & F. 2227 , op. 1 , spr. 651 \\
\hline & & 1863 & DAŻO & F. 90 , op. 1 , spr. 1232 \\
\hline & & 1871 & DAŻO & F. 90 , op. 1 , spr. 1265 \\
\hline & & 1881 & DAŻO & F. 90, op. 1, spr. 1306 \\
\hline \multirow{6}{*}{6.} & $\begin{array}{l}\text { Krzemieniec [Katerynburg, Kołodno, } \\
\text { Oleksiniec, Wiśniowie] }\end{array}$ & 1801 & DAŻO & F. 90 , op. 1 , spr. 230 \\
\hline & \multirow{5}{*}{$\begin{array}{l}\text { [Jampol, Krzemieniec, Łanowce, } \\
\text { Radziwiłłów, Szumsk, Szumbar, } \\
\text { Wiśniowiec] }\end{array}$} & $1881-1886$ & DAŻO & F. 90 , op. 1 , spr. 1340 \\
\hline & & 1886-1889 & DAŻO & F. 90, op. 1, spr. 1341 \\
\hline & & $1889-1895$ & DAŻO & F. 90 , op. 1, spr. 1342 \\
\hline & & 1894-1899 & DAŻO & F. 90 , op. 1, spr. 1343 \\
\hline & & 1899-1904 & DAŻO & F. 90, op. 1, spr. 1344 \\
\hline
\end{tabular}




\begin{tabular}{|c|c|c|c|c|}
\hline \multirow{6}{*}{7.} & Łuck pow. & 1796 & DAŻO & F. 90 , op. 1 , spr. 200 \\
\hline & \multirow{5}{*}{$\begin{array}{l}\text { Dekanat: [m.in. Nieświcz, Skórcze, } \\
\text { Sokul, Torczyn, Wiszenki] }\end{array}$} & 1801 & DAŻO & F. 90 , op. 1 , spr. 228 \\
\hline & & 1807 & DAŻO & F. 90 , op. 1, spr. 256 \\
\hline & & 1876 & DAŻO & F. 90 , op. 1 , spr. 1288 \\
\hline & & 1881 & DAŻO & F. 90, op. 1, spr. 1311 \\
\hline & & 1881 & DAŻO & F. 90 , op. 1 , spr. 1312 \\
\hline 8. & Nowogród Wołyński dek. & 1839 & DAŻO & F. 178, op. 51, spr. $73 ; 74$ \\
\hline \multirow{5}{*}{9.} & Ostróg pow. & 1799 & DAŻO & F. 178, op. 51, spr. 12 \\
\hline & \multirow{4}{*}{ Dekanat } & 1826 & DAŻO & F. 90 , op. 1 , spr. 714 \\
\hline & & 1841 & DAŻO & F. 90, op. 1, spr. 1097 \\
\hline & & 1850 & DAŻO & F. 90 , op. 1, spr. 1158 \\
\hline & & 1856 & DAŻO & F. 90 , op. 1, spr. 1203 \\
\hline 10. & Radomyśl & $1867-1871$ & CDIAU, Kijów & F. 1040 , op. 2 , spr. 482 \\
\hline \multirow{2}{*}{11.} & \multirow{2}{*}{ Równe } & 1845 & DAŻO & F. 90 , op. 1 , spr. 1136 \\
\hline & & $1871-1875$ & CDIAU, Kijów & F. 1045, op. 2, spr. 311 \\
\hline 12. & Stary Konstantynów pow. & $1856-1861$ & DAŻO & F. 178 , op. 51 , spr. 88 \\
\hline \multirow{10}{*}{13.} & $\begin{array}{l}\text { Włodzimierz Wołyński okręg [kościo- } \\
\text { ły parafialne i klasztory] }\end{array}$ & $1791-1798$ & CDIAU, Kijów & F. 2227, op.1, spr. 649 \\
\hline & \multirow{9}{*}{ Dekanat } & 1851 & DAŻO & F. 90, op. 1, spr. 1164 \\
\hline & & $1856-1861$ & DAŻO & F. 90, op. 1, spr. 1191 \\
\hline & & 1861 & DAŻO & F. 90 , op. 1, spr. 1223 \\
\hline & & 1871 & DAŻO & F. 90 , op. 1, spr. 1263 \\
\hline & & 1876 & DAŻO & F. 90, op. 1, spr. 1281 \\
\hline & & 1881 & DAŻO & F. 90 , op. 1 , spr. 1298 \\
\hline & & 1881 & DAŻO & F. 90, op. 1, spr. 1299 \\
\hline & & 1881 & DAŻO & F. 90, op. 1 , spr. 1300 \\
\hline & & 1888 & DAŻO & F. 90, op. 1 , spr. 1315 \\
\hline \multirow{4}{*}{14.} & \multirow{2}{*}{ Żytomierz dek. } & 1813 & DAŻO & F. 90 , op. 1 , spr. 280 \\
\hline & & 1855 & DAŻO & F. 178 , op. 2 , spr. 1068 \\
\hline & \multirow{2}{*}{ [bez miasta Żytomierz] } & $1856-1861$ & DAŻO & F. 402 , op. 1 , spr. 2 \\
\hline & & $1876-1880$ & DAŻO & F. 402 , op. 1 , spr. 5 \\
\hline \multicolumn{2}{|c|}{ Ogółem } & 1791-1904 & \multicolumn{2}{|r|}{51 poszytów } \\
\hline & Parafia/kościól & Lata & Archiwum & Sygnatura \\
\hline \multirow{13}{*}{1.} & \multirow{13}{*}{ Aleksandria, dek. Równe } & $1818-1820$ & DAŻO & $\begin{array}{l}\text { F. 90, op. 1, spr. } 311 ; 364 \text {; } \\
417\end{array}$ \\
\hline & & $1822-1830$ & DAŻO & $\begin{array}{l}\text { F. } 90, \text { op. 1, spr. 468; 519; } \\
570 ; 621 ; 673 ; 726 ; 779 ; \\
830 ; 880\end{array}$ \\
\hline & & 1832 & DAŻO & F. 90 , op. 1 , spr. $987 ; 988$ \\
\hline & & 1833 & DAŻO & F. 90, op. 1, spr. 1031 \\
\hline & & 1839 & DAŻO & F. 90 , op. 2. spr. 11 \\
\hline & & 1841-1842 & DAŻO & F. 90 , op. 1 , spr. $1081 ; 1101$ \\
\hline & & 1850 & DAŻO & F. 90 , op. 1 , spr. 1143 \\
\hline & & 1855 & DAŻO & F. 90, op. 1, spr. 1177 \\
\hline & & 1861 & DAŻO & F. 90, op. 1, spr. 1219 \\
\hline & & 1863 & DAŻO & F. 90 , op. 1 , spr. 1230 \\
\hline & & 1866 & DAŻO & F. 90 , op. 1, spr. 1241 \\
\hline & & 1871 & CDIAU, Kijów & F. 1045 , op. 2 , spr. 133 \\
\hline & & 1876 & DAŻO & F. 90 , op. 1 , spr. 1278 \\
\hline
\end{tabular}




\begin{tabular}{|c|c|c|c|c|}
\hline \multirow{2}{*}{2.} & \multirow{2}{*}{ Annopol, dek. Ostróg } & 1844 & DAŻO & F. 90, op. 1, spr. 1119 \\
\hline & & 1866 & DAŻO & F. 90, op. 1 , spr. 1240 \\
\hline 3. & Bałta, dek. Bałta & $1844(1846)$ & DAChO & F. 685 , op. 2, spr. 24 \\
\hline \multirow{6}{*}{4.} & \multirow{6}{*}{$\begin{array}{l}\text { Berdyczów, fara } \\
\text { dek. Berdyczów }\end{array}$} & 1796-1799 & CDIAU, Kijów & F. 1046, op. 1, spr. 4 \\
\hline & & 1799 & DAŻO & F. 90, op. 2 , spr. 1 \\
\hline & & 1822 & CDIAU, Kijów & F. 1046 , op. 1 , spr. 11 \\
\hline & & $1830-1831$ & CDIAU, Kijów & F. 1046 , op. 1 , spr. 13 \\
\hline & & 1836 & CDIAU, Kijów & F. 1046 , op. 1 , spr. 14 \\
\hline & & $1839 ; 1841$ & CDIAU, Kijów & F. 1046 , op. 1 , spr. 16 \\
\hline \multirow{7}{*}{5.} & \multirow{7}{*}{ Beresteczko, dek. Dubno } & $1841-1842$ & DAŻO & F. 90, op. 1 , spr. $1082 ; 1104$ \\
\hline & & $1844-1845$ & DAŻO & F. 90 , op. 1 , spr. $1121 ; 1129$ \\
\hline & & 1850 & DAŻO & F. 90, op. 1, spr. 1145 \\
\hline & & 1855 & DAŻO & F. 90, op. 1, spr. 1179 \\
\hline & & 1860 & DAŻO & F. 90, op. 1, spr. 1211 \\
\hline & & 1865 & DAŻO & F. 90, op. 1 , spr. 1234 \\
\hline & & 1870 & DAŻO & F. 90, op. 1 , spr. 1258 \\
\hline \multirow{7}{*}{6.} & \multirow{7}{*}{$\begin{array}{l}\text { Berezdów, dek. Nowogród Wołyński } \\
\text { (później Równe) }\end{array}$} & $1818-1819$ & DAŻO & F. 178, op. 51, spr. $17 ; 24$ \\
\hline & & 1822 & DAŻO & F. 178 , op. 51 , spr. 35 \\
\hline & & $1824-1825$ & DAŻO & F. 178, op. 51 , spr. $38 ; 41$ \\
\hline & & 1828 & DAŻO & F. 178 , op. 51 , spr. 53 \\
\hline & & 1849 & CDIAU, Kijów & F. 1045 , op. 2 , spr. 306 \\
\hline & & 1855 & CDIAU, Kijów & F. 1045 , op. 2 , spr. 308 \\
\hline & & 1856 & DAŻO & F. 178 , op. 51 , spr. 84 \\
\hline 7. & $\begin{array}{l}\text { Berezianka, par. Topory, } \\
\text { dek. Skwira }\end{array}$ & 1830 & CDIAU, Kijów & F. 1041 , op. 1 , spr. 3 \\
\hline \multirow{12}{*}{8.} & \multirow{12}{*}{ Bereźne, dek. Równe } & 1807 & DAŻO & F. 90 , op. 1 , spr. 246 \\
\hline & & $1818-1820$ & DAŻO & $\begin{array}{l}\text { F. } 90 \text {, op. } 1 \text {, spr. } 312 ; 367 \text {; } \\
422\end{array}$ \\
\hline & & $1823-1833$ & DAŻO & $\begin{array}{l}\text { F. } 90, \text { op. 1, spr. 523; 572; } \\
623 ; 677 ; 728 ; 781 ; 835 \text {; } \\
883 ; 939 ; 990 ; 1035\end{array}$ \\
\hline & & 1839 & DAŻO & F. 90 , op. 1 , spr. 1075 \\
\hline & & 1842 & DAŻO & F. 90 , op. 1 , spr. 1102 \\
\hline & & 1844 & DAŻO & F. 90, op. 1 , spr. 1120 \\
\hline & & 1850 & DAŻO & F. 90 , op. 1 , spr. 1146 \\
\hline & & 1855 & DAŻO & F. 90 , op. 1 , spr. 1178 \\
\hline & & $1855-1860$ & CDIAU, Kijów & F. 1045 , op. 1 , spr. 167 \\
\hline & & $1860-1861$ & DAŻO & F. 90, op. 1 , spr. $1210 ; 1221$ \\
\hline & & 1866 & DAŻO & F. 90 , op. 1 , spr. 1242 \\
\hline & & 1876 & DAŻO & F. 90, op. 1 , spr. 1279 \\
\hline \multirow{7}{*}{9.} & \multirow{7}{*}{ Bereźnicka, dek. Łuck } & 1807 & DAŻO & F. 90 , op. 1 , spr. 247 \\
\hline & & $1819-1820$ & DAŻO & F. 90, op. 1 , spr. $368 ; 418$ \\
\hline & & $1822-1833$ & DAŻO & $\begin{array}{l}\text { F. } 90, \text { op. } 1 \text {, spr. 471; 520; } \\
573 ; 624 ; 675 ; 727 ; 780 \text {; } \\
832 ; 884 ; 935 ; 989 ; 1032\end{array}$ \\
\hline & & 1842 & DAŻO & F. 90, op. 1 , spr. 1103 \\
\hline & & 1849 & CDIAU, Kijów & F. 2227, op. 1 , spr. 680 \\
\hline & & 1850 & DAŻO & F. 90 , op. 1 , spr. 1144 \\
\hline & & 1856 & DAŻO & F. 90, op. 1 , spr. 1188 \\
\hline
\end{tabular}




\begin{tabular}{|c|c|c|c|c|}
\hline 10. & Białogródka, dek. Zasław & 1805 & DAŻO & F. 90 , op. 2 , spr. 4 \\
\hline \multirow{3}{*}{11.} & \multirow{3}{*}{$\begin{array}{l}\text { Białopol, dek. Machnówka } \\
\text { [dek. Swirsko-Lipowiecki] }\end{array}$} & 1809 & DAŻO & F. 90 , op. 1 , spr. 276 \\
\hline & & $\begin{array}{l}1820 ; 1832 ; \\
1835 ; 1836\end{array}$ & CDIAU, Kijów & F. 1046 , op. 1 , spr. 10 \\
\hline & & 1831 & DAŻO & F. 90 , op. 1, spr. 937 \\
\hline \multirow{11}{*}{12.} & \multirow{11}{*}{ Białozórka, dek. Krzemieniec } & 1807 & DAŻO & F. 90 , op. 1 , spr. 245 \\
\hline & & $1817-1818$ & DAŻO & F. 90 , op. 1 , spr. $294 ; 313$ \\
\hline & & 1820 & DAŻO & F. 90 , op. 1, spr. 421 \\
\hline & & 1823 & DAŻO & F. 90 , op. 1 , spr. 521 \\
\hline & & $1825-1833$ & DAŻO & $\begin{array}{l}\text { F. } 90 \text {, op. 1, spr. 622; 676; } \\
730 ; 782 ; 833 ; 882 ; 936 ; \\
991 ; 1034\end{array}$ \\
\hline & & 1845 & DAŻO & F. 90, op. 1, spr. 1131 \\
\hline & & 1856 & DAŻO & F. 90 , op. 1 , spr. 1187 \\
\hline & & $1860-1861$ & DAŻO & F. 90, op. 1 , spr. $1212 ; 1220$ \\
\hline & & 1866 & DAŻO & F. 90 , op. 1 , spr. 1243 \\
\hline & & 1871 & DAŻO & F. 90, op. 1, spr. 1262 \\
\hline & & 1876 & DAŻO & F. 90 , op. 1 , spr. 1280 \\
\hline 13. & $\begin{array}{l}\text { Borszczów [Borszczajów], dek. Skwi- } \\
\text { ra }\end{array}$ & 1830 & CDIAU, Kijów & F. 1040 , op. 1 , spr. 16 \\
\hline 14. & Brusiłów, dek. Radomyśl & $1867-1872$ & CDIAU, Kijów & F. 1040, op. 2, spr. 481 \\
\hline \multirow{5}{*}{15.} & \multirow{5}{*}{ Buceń, dek. Kowel } & $1818-1820$ & DAŻO & $\begin{array}{l}\text { F. } 90 \text {, op. } 1 \text {, spr. } 314 ; 365 \text {; } \\
420\end{array}$ \\
\hline & & $1822-1824$ & DAŻO & $\begin{array}{l}\text { F. } 90 \text {, op. 1, spr. 469; 522; } \\
571\end{array}$ \\
\hline & & $1826-1833$ & DAŻO & $\begin{array}{l}\text { F. 90, op. 1, spr. 674; 729; } \\
783 ; 834 ; 881 ; 938 ; 992 ; \\
1033\end{array}$ \\
\hline & & 1856 & DAŻO & F. 90, op. 1, spr. 1189 \\
\hline & & 1899 & DAŻO & F. 90 , op. 1 , spr. 1335 \\
\hline 16. & Butowce dek. Zasław & 1807 & DAŻO & F. 90 , op. 1 , spr. 248 \\
\hline \multirow[b]{2}{*}{17.} & \multirow[b]{2}{*}{ Cudnów, dek. Żytomierz } & $1818-1819$ & DAŻO & F. 178 , op. 51 , spr. $23 ; 27$ \\
\hline & & $1824-1827$ & DAŻO & $\begin{array}{l}\text { F. } 178 \text {, op. } 51 \text {, spr. } 40 ; 43 ; \\
46 ; 49\end{array}$ \\
\hline 18. & Czarnobyl, dek. Radomyśl & $1876-1881$ & CDIAU, Kijów & F. 1040 , op. 2 , spr. 484 \\
\hline 19. & Czarny Ostrów, dek. Płoskirów & 1888 & DAŻO & F. 90, op. 1, spr. 1329 \\
\hline 20. & $\begin{array}{l}\text { Czopowicze, par. Malin, } \\
\text { dek. Radomyśl }\end{array}$ & 1830 & CDIAU, Kijów & F. 1040 , op. 1 , spr. 18 \\
\hline \multirow{4}{*}{21.} & \multirow{4}{*}{ Dąbrowica, dek. Łuck } & 1841 & DAŻO & F. 90, op. 1, spr. 1086 \\
\hline & & 1844 & DAŻO & F. 90, op. 1, spr. $1120 ; 1123$ \\
\hline & & 1850 & DAŻO & F. 90, op. 1, spr. 1149 \\
\hline & & 1851 & DAŻO & F. 90, op. 1 , spr. 1165 \\
\hline \multirow{2}{*}{22.} & \multirow{2}{*}{$\begin{array}{l}\text { Derażnia (Derażne), } \\
\text { dek. Równe }\end{array}$} & 1849 & CDIAU, Kijów & F. 1045 , op. 2 , spr. 305 \\
\hline & & 1861 & CDIAU, Kijów & F. 1045 , op. 2 , spr. 310 \\
\hline 23. & Didowszczyzna, dek. Skwira & 1888 & DAŻO & F. 90 , op. 1, spr. 1316 \\
\hline \multirow{4}{*}{24.} & \multirow{4}{*}{ Dubno, dek. Dubno } & 1807 & DAŻO & F. 90, op. 1, spr. 252 \\
\hline & & 1819 & DAŻO & F. 90 , op. 1, spr. 380 \\
\hline & & 1832 & DAŻO & F. 90, op. 1, spr. 999 \\
\hline & & 1841 & DAŻO & F. 90, op. 1, spr. 1087 \\
\hline
\end{tabular}




\begin{tabular}{|c|c|c|c|c|}
\hline 25. & Felsztyn, dek. Płoskirów & 1888 & DAŻO & F. 90 , op. 1 , spr. 1328 \\
\hline \multirow{3}{*}{26.} & \multirow{3}{*}{ Hołoby, dek. Kowel } & $1818-1820$ & DAŻO & $\begin{array}{l}\text { F. } 178 \text {, op. } 51 \text {, spr. } 18 ; 25 \text {; } \\
30\end{array}$ \\
\hline & & $1822-1833$ & DAŻO & $\begin{array}{l}\text { F. } 178, \text { op. } 51 \text {, spr. } 36 ; 37 \text {; } \\
39 ; 42 ; 45 ; 47 ; 55 ; 56 ; 60 \text {; } \\
61 ; 64 ; 66\end{array}$ \\
\hline & & 1856 & DAŻO & F. 178, op. 51, spr. 85 \\
\hline \multirow{2}{*}{27.} & \multirow{2}{*}{ Horbulów, dek. Radomyśl } & 1830 & CDIAU, Kijów & F. 1040 , op. 1 , spr. 20 \\
\hline & & $1876-1881$ & CDIAU, Kijów & F. 1040, op. 2 , spr. 485 \\
\hline \multirow{11}{*}{28.} & \multirow{11}{*}{ Horyngród, dek. Równe } & 1799 & DAŻO & F. 90, op. 1, spr. 204 \\
\hline & & $1818-1820$ & DAŻO & $\begin{array}{l}\text { F. } 90 \text {, op. } 1 \text {, spr. } 317 ; 373 \text {; } \\
427\end{array}$ \\
\hline & & $1822-1833$ & DAŻO & $\begin{array}{l}\text { F. } 90, \text { op. } 1 \text {, spr. 477; 528; } \\
577 ; 629 ; 723 ; 735 ; 787 \text {; } \\
839 ; 932 ; 975 ; 995 ; 1039\end{array}$ \\
\hline & & 1839 & DAŻO & F. 90 , op. 1 , spr. 1076 \\
\hline & & $1841-1842$ & DAŻO & F. 90, op. 1, spr.1084; 1114 \\
\hline & & 1849 & CDIAU, Kijów & F. 1044, op. 1, spr. 8 \\
\hline & & 1850 & DAŻO & F. 90, op. 1 , spr. 1163 \\
\hline & & 1853 & CDIAU, Kijów & F. 1045 , op. 2 , spr. 307 \\
\hline & & 1855 & DAŻO & F. 90 , op. 1 , spr. 1186 \\
\hline & & 1861 & DAŻO & F. 90, op. 1 , spr. 1231 \\
\hline & & 1867 & DAŻO & F. 90 , op. 1 , spr. 1257 \\
\hline \multirow{4}{*}{29.} & \multirow{4}{*}{ Hulewiczów, dek. Kowel } & 1799 & DAŻO & F. 90, op. 1 , spr. 203 \\
\hline & & $1818-1820$ & DAŻO & $\begin{array}{l}\text { F. } 90 \text {, op. } 1 \text {, spr. } 318 ; 374 ; \\
426\end{array}$ \\
\hline & & $1822-1833$ & DAŻO & $\begin{array}{l}\text { F. 90, op. } 1 \text {, spr. 476; 529; } \\
582 ; 628 ; 681 ; 734 ; 788 \text {; } \\
838 ; 889 ; 942 ; 996 ; 1038\end{array}$ \\
\hline & & 1856 & DAŻO & F. 90, op. 1 , spr. 1192 \\
\hline 30. & Iwanków, dek. Radomyśl & 1834 & CDIAU, Kijów & F. 1040 , op. 2 , spr. 477 \\
\hline 31. & Jampol, dek. Jampol (Podole) & 1827 & DAChO & F. 685 , op. 4 , spr. 26 \\
\hline \multirow{2}{*}{32.} & \multirow{2}{*}{ Jampol, dek. Krzemieniec } & 1807 & DAŻO & F. 90 , op. 1 , spr. 274 \\
\hline & & 1819 & DAŻO & F. 178, op. 51 , spr. 28 \\
\hline 33. & Jarmolińce, dek. Płoskirów & 1888 & DAŻO & F. 90, op. 1 , spr. 1331 \\
\hline \multirow{3}{*}{34.} & \multirow{3}{*}{ Kamieniec Podolski, katedra } & 1871 & DAŻO & F. 90, op. 1, spr. 1266 \\
\hline & & $1876-1880$ & DAŻO & F. 90 , op. 1 , spr. 1287 \\
\hline & & $1881-1886$ & DAŻO & F. 90 , op. 1, spr. 1307-1309 \\
\hline \multirow{2}{*}{35.} & \multirow{2}{*}{ Kamień Koszyrski, dek. Kowel } & 1833 & DAŻO & F. 90 , op. 1 , spr. 1045 \\
\hline & & 1856 & DAŻO & F. 90, op. 1 , spr. 1196 \\
\hline \multirow{3}{*}{36.} & \multirow{3}{*}{ Kazimirka, dek. Równe } & 1799 & DAŻO & F. 90 , op. 1 , spr. 206 \\
\hline & & 1849 & CDIAU, Kijów & F. 1045 , op. 2 , spr. 302 \\
\hline & & 1876 & CDIAU, Kijów & F. 1045 , op. 2 , spr. 315 \\
\hline
\end{tabular}




\begin{tabular}{|c|c|c|c|c|}
\hline \multirow{12}{*}{37.} & \multirow{12}{*}{ Klewań, dek. Równe } & 1799 & DAŻO & F. 90 , op. 1, spr. 207 \\
\hline & & 1820 & DAŻO & F. 90 , op. 1, spr. 434 \\
\hline & & $1822-1833$ & DAŻO & $\begin{array}{l}\text { F. } 90, \text { op. } 1 \text {, spr. 491; 539; } \\
587 ; 644 ; 691 ; 751 ; 800 ; \\
848 ; 901 ; 958 ; 1003 ; 1048\end{array}$ \\
\hline & & 1838 & DAŻO & F. 90, op. 1, spr. 1074 \\
\hline & & $1841-1842$ & DAŻO & F. 90, op. 1, spr.1089; 1107 \\
\hline & & $1849-1850$ & DAŻO & F. 90, op. 1 , spr. $1142 ; 1153$ \\
\hline & & 1855 & DAŻO & F. 90 , op. 1 , spr. $1182 ; 1183$ \\
\hline & & $1860-1861$ & DAŻO & F. 90 , op. 1 , spr. $1216 ; 1225$ \\
\hline & & 1860 & CDIAU, Kijów & F. 1045, op. 2, spr. 309 \\
\hline & & 1871 & DAŻO & F. 90 , op. 1 , spr. 1270 \\
\hline & & 1874 & CDIAU, Kijów & F. 1045 , op. 2 , spr. $311 ; 313$ \\
\hline & & 1876 & DAŻO & F. 90 , op. 1 , spr. 1285 \\
\hline 38. & Kodnia, dek. Żytomierz & 1838 & DAŻO & F. 90 , op. 1 , spr. 1073 \\
\hline \multirow{6}{*}{39.} & \multirow{6}{*}{ Kołki, dek. Łuck } & 1808 & DAŻO & F. 90 , op. 1 , spr. 275 \\
\hline & & $1818-1820$ & DAŻO & $\begin{array}{l}\text { F. } 90 \text {, op. } 1 \text {, spr. } 331 ; 387 \text {; } \\
441\end{array}$ \\
\hline & & $1822-1833$ & DAŻO & $\begin{array}{l}\text { F. 90, op. 1, spr. 490; 546; } \\
590 ; 642 ; 693 ; 750 ; 804 ; \\
902 ; 957 ; 1007 ; 1050\end{array}$ \\
\hline & & 1844 & DAŻO & F. 90 , op. 1, spr. 1120 \\
\hline & & $1850-1851$ & DAŻO & F. 90, op. 1, spr. $1152 ; 1166$ \\
\hline & & 1871 & DAŻO & F. 90, op. 1, spr. 1269 \\
\hline \multirow{3}{*}{40.} & \multirow{3}{*}{ Kołodno, dek. Krzemieniec } & 1799 & DAŻO & F. 90, op. 1, spr. 209 \\
\hline & & 1818 & DAŻO & F. 90 , op. 1 , spr. 333 \\
\hline & & 1866 & DAŻO & F. 90, op. 1, spr. 1247 \\
\hline 41. & Koniuchy, dek. Włodzimierz & 1801 & DAŻO & F. 90 , op. 1, spr. 231 \\
\hline \multirow{3}{*}{42.} & \multirow{3}{*}{$\begin{array}{l}\text { Korosteszów (Korostyszów), } \\
\text { dek. Radomyśl }\end{array}$} & 1843 & CDIAU, Kijów & F. 1040 , op. 2 , spr. 480 \\
\hline & & $1871-1875$ & CDIAU, Kijów & F. 1040, op. 2, spr. 483 \\
\hline & & $1889-1894$ & CDIAU, Kijów & F. 1040, op. 2, spr. 486 \\
\hline \multirow{3}{*}{43.} & \multirow{3}{*}{ Korytnica, dek. Włodzimierz } & 1799 & DAŻO & F. 90 , op. 1, spr. 212 \\
\hline & & $1818-1820$ & DAŻO & $\begin{array}{l}\text { F. } 90 \text {, op. } 1 \text {, spr. } 330 ; 388 ; \\
442\end{array}$ \\
\hline & & $1822-1833$ & DAŻO & $\begin{array}{l}\text { F. 90, op. 1, spr. 487; 545; } \\
591 ; 643 ; 694 ; 748 ; 798 ; \\
850 ; 904 ; 953 ; 1008 ; 1047\end{array}$ \\
\hline 44. & Korzec, dek. Równe & 1825 & DAŻO & F. 90, op. 1, spr. 637 \\
\hline 45. & Koszowata, dek. Humań & 1831 & DAŻO & F. 90 , op. 1 , spr. 952 \\
\hline \multirow{2}{*}{46.} & \multirow{2}{*}{ Kotelnia, dek. Żytomierz } & 1818 & DAŻO & F. 178 , op. 51 , spr. 22 \\
\hline & & 1829 & DAŻO & F. 178 , op. 51 , spr. 58 \\
\hline \multirow{5}{*}{47.} & \multirow{5}{*}{ Kowel, dek. Kowel } & 1799 & DAŻO & F. 90 , op. 1, spr. 211 \\
\hline & & $1819-1820$ & DAŻO & F. 90 , op. 1 , spr. $390 ; 440$ \\
\hline & & $1822-1833$ & DAŻO & $\begin{array}{l}\text { F. 90, op. 1, spr. 494; 541; } \\
589 ; 645 ; 690 ; 695 ; 746 ; \\
803 ; 849 ; 903 ; 954 ; 1004 \\
1046\end{array}$ \\
\hline & & 1856 & DAŻO & F. 90, op. 1, spr. 1194 \\
\hline & & 1866 & DAŻO & F. 90 , op. 1 , spr. 1248 \\
\hline
\end{tabular}




\begin{tabular}{|c|c|c|c|c|}
\hline \multirow{10}{*}{48.} & \multirow{10}{*}{ Krupiec, dek. Dubno } & 1799 & DAŻO & F. 90 , op. 1 , spr. 208 \\
\hline & & $1818-1820$ & DAŻO & $\begin{array}{l}\text { F. } 90 \text {, op. } 1 \text {, spr. } 332 ; 391 ; \\
439\end{array}$ \\
\hline & & $1822-1831$ & DAŻO & $\begin{array}{l}\text { F. } 90, \text { op. } 1 \text {, spr. 493; 540; } \\
588 ; 646 ; 689 ; 752 ; 799 \\
847 ; 905 ; 955\end{array}$ \\
\hline & & 1833 & DAŻO & F. 90, op. 1, spr. 1044 \\
\hline & & 1841-1842 & DAŻO & F. 90, op. 1 , spr. $1090 ; 1108$ \\
\hline & & $1844-1845$ & DAŻO & F. 90, op. 1 , spr. $1125 ; 1133$ \\
\hline & & 1850 & DAŻO & F. 90, op. 1 , spr. 1154 \\
\hline & & 1855 & DAŻO & F. 90, op. 1 , spr. 1181 \\
\hline & & 1860 & DAŻO & F. 90, op. 1 , spr. 1215 \\
\hline & & 1865 & DAŻO & F. 90, op. 1, spr. 1236 \\
\hline \multirow{8}{*}{49.} & \multirow{8}{*}{ Krzemieniec, dek. Krzemieniec } & 1816 & DAŻO & F. 90, op. 1, spr. 288 \\
\hline & & $1818-1820$ & DAŻO & $\begin{array}{l}\text { F. } 90 \text {, op. } 1 \text {, spr. } 328 ; 389 \text {; } \\
435\end{array}$ \\
\hline & & $1822-1831$ & DAŻO & $\begin{array}{l}\text { F. } 90 \text {, op. } 1 \text {, spr. 488; } 543 \text {; } \\
585 ; 640 ; 692 ; 749 ; 802 \text {; } \\
852 ; 897 ; 949\end{array}$ \\
\hline & & 1845 & DAŻO & F. 90, op. 1, spr. 1132 \\
\hline & & 1856 & DAŻO & F. 90, op. 1 , spr. $1193 ; 1195$ \\
\hline & & 1861 & DAŻO & F. 90, op. 1 , spr. 1224 \\
\hline & & 1871 & DAŻO & F. 90, op. 1 , spr. $1267 ; 1268$ \\
\hline & & $1876-1881$ & DAŻO & F. 90, op. 1, spr. 1286 \\
\hline 50. & Krzywin, dek. Ostróg & 1799 & DAŻO & F. 90 , op. 1 , spr. 213 \\
\hline 51. & Kumanów, dek. Płoskirów & 1888 & DAŻO & F. 90, op. 1 , spr. 1318 \\
\hline \multirow{6}{*}{52.} & \multirow{6}{*}{ Kuniów, dek. Ostróg } & 1799 & DAŻO & F. 90 , op. 1 , spr. 210 \\
\hline & & $1818-1820$ & DAŻO & $\begin{array}{l}\text { F. } 90 \text {, op. } 1 \text {, spr. } 335 ; 386 \text {; } \\
438\end{array}$ \\
\hline & & $1822-1833$ & DAŻO & $\begin{array}{l}\text { F. 90, op. } 1 \text {, spr. 489; 542; } \\
594 ; 638 ; 696 ; 745 ; 805 \text {; } \\
853 ; 899 ; 951 ; 1005 ; 1006 \text {; } \\
1049\end{array}$ \\
\hline & & 1841 & DAŻO & F. 90, op. 1 , spr. 1091 \\
\hline & & 1843-1844 & DAŻO & F. 90, op. 1 , spr. $1115 ; 1126$ \\
\hline & & 1866 & DAŻO & F. 90, op. 1, spr. 1249 \\
\hline 53. & Latyczów, dek. Latyczów & 1865 & DAŻO & F. 90 , op. 1 , spr. 1238 \\
\hline \multirow[b]{2}{*}{54.} & \multirow[b]{2}{*}{ Leszczyn, dek. Żytomierz } & 1805 & DAŻO & F. 90 , op. 1 , spr. 243 \\
\hline & & 1818 & DAŻO & $\begin{array}{l}\text { F. } 90 \text {, op. 1, spr. } 336, \text { k. } 1-2 ; \\
338\end{array}$ \\
\hline 55. & Lipowiec, dek. Lipowiec & 1831 & DAŻO & F. 90 , op. 1 , spr. 961 \\
\hline \multirow{6}{*}{56.} & \multirow{6}{*}{ Litowiż, dek. Włodzimierz } & 1801 & DAŻO & F. 90 , op. 1 , spr. 233 \\
\hline & & 1818 & DAŻO & F. 90, op. 1 , spr. 339 \\
\hline & & 1820 & DAŻO & F. 90, op. 1 , spr. 445 \\
\hline & & $1822-1831$ & DAŻO & $\begin{array}{l}\text { F. } 90, \text { op. } 1 \text {, spr. 499; 547; } \\
598 ; 647 ; 703 ; 758 ; 809 \\
855 ; 912 ; 960\end{array}$ \\
\hline & & 1833 & DAŻO & F. 90, op. 1, spr. 1051 \\
\hline & & 1866 & DAŻO & F. 90 , op. 1 , spr. 1252 \\
\hline
\end{tabular}




\begin{tabular}{|c|c|c|c|c|}
\hline 57. & Lityn, dek. Lityn & 1829 & DAŻO & F. 90 , op. 1 , spr. 856 \\
\hline \multirow{6}{*}{58.} & \multirow{6}{*}{ Luboml, dek. Kowel } & 1801 & DAŻO & F. 90 , op. 1, spr. 234 \\
\hline & & $1818-1820$ & DAŻO & $\begin{array}{l}\text { F. } 90 \text {, op. } 1 \text {, spr. } 340 ; 392 ; \\
446\end{array}$ \\
\hline & & 1822 & DAŻO & F. 90 , op. 1 , spr. 498 \\
\hline & & $1824-1833$ & DAŻO & $\begin{array}{l}\text { F. 90, op. 1, spr. 596; 652; } \\
700 ; 754 ; 807 ; 857 ; 910 ; \\
959 ; 1014 ; 1053\end{array}$ \\
\hline & & 1856 & DAŻO & F. 90, op. 1, spr. 1198 \\
\hline & & 1899 & DAŻO & F. 90 , op. 1 , spr. 1336 \\
\hline 59. & Łuck, kościół i seminarium & 1820 & DAŻO & F. 178 , op. 51 , spr. 31 \\
\hline \multirow{14}{*}{60.} & \multirow{14}{*}{ Łuck, katedra } & 1807 & DAŻO & F. 90 , op. 1 , spr. 255 \\
\hline & & 1813 & DAŻO & F. 90, op. 1, spr. 279 \\
\hline & & 1822 & DAŻO & F. 90 , op. 1, spr. 496 \\
\hline & & 1830 & DAŻO & F. 90 , op. 1 , spr. 908 \\
\hline & & 1832 & DAŻO & F. 90, op. 1, spr. 1013 \\
\hline & & 1833 & DAŻO & F. 90 , op. 1 , spr. $1056 ; 1057$ \\
\hline & & 1841 & DAŻO & F. 178 , op. 4, spr. 287 \\
\hline & & 1852 & DAŻO & F. 90 , op. 1, spr. 1176 \\
\hline & & 1856 & DAŻO & F. 90, op. 1, spr. 1197 \\
\hline & & 1866 & DAŻO & F. 90 , op. 1, spr. 1251 \\
\hline & & 1871 & DAŻO & F. 90 , op. 1, spr. 1271 \\
\hline & & 1876 & DAŻO & F. 90 , op. 1 , spr. 1289 \\
\hline & & 1877 & DAŻO & F. 90 , op. 1 , spr. 1295 \\
\hline & & 1881 & DAŻO & F. 90 , op. 1 , spr. 1310 \\
\hline \multirow{7}{*}{61.} & \multirow{7}{*}{ Łysin, dek. Dubno } & 1816 & DAŻO & F. 90, op. 1, spr. 292 \\
\hline & & 1824 & DAŻO & F. 90, op. 1, spr. 599 \\
\hline & & 1830 & DAŻO & F. 90 , op. 1, spr. 907 \\
\hline & & 1842 & DAŻO & F. 90, op. 1, spr. 1109 \\
\hline & & 1860 & DAŻO & F. 90 , op. 1, spr. 1217 \\
\hline & & $1865-1866$ & DAŻO & F. 90 , op. 1 , spr. $1237 ; 1250$ \\
\hline & & 1870 & DAŻO & F. 90 , op. 1 , spr. 1260 \\
\hline 62. & Maciejów, dek. Kowel & 1799 & DAŻO & F. 90, op. 1, spr. 216 \\
\hline \multirow{3}{*}{63.} & \multirow{3}{*}{ Malin, dek. Radomyśl } & 1799 & DAŻO & F. 90 , op. 1 , spr. 215 \\
\hline & & 1830 & CDIAU, Kijów & F. 1040, op. 1, spr. 17 \\
\hline & & $\begin{array}{c}1839 ; 1867- \\
1869\end{array}$ & CDIAU, Kijów & F. 1040 , op. 2 , spr. 479 \\
\hline 64. & Mańkowce, dek. Lityn & $1796-1886$ & DAChO & F. 685 , op. 3 , spr. 1 \\
\hline 65. & Michałkowce, dek. Płoskirów & 1888 & DAŻO & F. 90, op. 1, spr. 1319 \\
\hline 66. & Mielnica, dek. Kowel & 1799 & DAŻO & F. 90, op. 1, spr. 214 \\
\hline \multirow{4}{*}{67.} & \multirow{4}{*}{$\begin{array}{l}\text { Międzyrzec Korecki, } \\
\text { dek. Równe }\end{array}$} & 1855 & DAŻO & F. 90 , op. 1 , spr. 1184 \\
\hline & & $1865-1866$ & DAŻO & F. 90 , op. 1 , spr. $1239 ; 1253$ \\
\hline & & 1871 & DAŻO & F. 90, op. 1, spr. 1272 \\
\hline & & 1876 & DAŻO & F. 90 , op. 1 , spr. 1290 \\
\hline
\end{tabular}




\begin{tabular}{|c|c|c|c|c|}
\hline \multirow{6}{*}{68.} & \multirow{6}{*}{ Nabrzuska, dek. Kowel } & 1799 & DAŻO & F. 90 , op. 1, spr. 217 \\
\hline & & $1818-1820$ & DAŻO & $\begin{array}{l}\text { F. } 90 \text {, op. } 1 \text {, spr. } 346 ; 398 \text {; } \\
452\end{array}$ \\
\hline & & $1822-1824$ & DAŻO & $\begin{array}{l}\text { F. } 90 \text {, op. } 1 \text {, spr. } 504 ; 555 \text {; } \\
602\end{array}$ \\
\hline & & $1826-1833$ & DAŻO & $\begin{array}{l}\text { F. } 90 \text {, op. } 1 \text {, spr. } 709 ; 761 ; \\
815 ; 865 ; 924 ; 968 ; 1019 ; \\
1060\end{array}$ \\
\hline & & 1840 & DAŻO & F. 90 , op. 1 , spr. $1080 \mathrm{a}$ \\
\hline & & 1856 & DAŻO & F. 90, op. 1 , spr. 1199 \\
\hline \multirow{2}{*}{69.} & \multirow{2}{*}{ Narodycze, dek. Owrucz } & 1807 & DAŻO & F. 90 , op. 1, spr. 259 \\
\hline & & 1815 & DAŻO & F. 90, op. 1 , spr. 282 \\
\hline \multirow{7}{*}{70.} & \multirow{7}{*}{ Nieświcz, dek. Łuck } & 1807 & DAŻO & F. 90 , op. 1 , spr. 260 \\
\hline & & 1820 & DAŻO & F. 90 , op. 1 , spr. 453 \\
\hline & & $1822-1827$ & DAŻO & $\begin{array}{l}\text { F. } 90 \text {, op. } 1 \text {, spr. } 502 ; 554 ; \\
604 ; 656 ; 708 ; 763\end{array}$ \\
\hline & & $1829-1833$ & DAŻO & $\begin{array}{l}\text { F. 90, op. } 1 \text {, spr. } 864 ; 925 ; \\
966 ; 1018 ; 1059\end{array}$ \\
\hline & & 1841 & DAŻO & F. 90, op. 1, spr. 1095 \\
\hline & & 1851 & DAŻO & F. 90 , op. 1 , spr. 1168 \\
\hline & & 1857 & DAŻO & F. 90 , op. 1 , spr. 1209 \\
\hline \multirow{8}{*}{71.} & \multirow{8}{*}{ Niewirków, dek. Równe } & 1839 & DAŻO & F. 90, op. 1 , spr. 1079 \\
\hline & & $1841-1842$ & DAŻO & F. 90, op. 1, spr. 1094; 1111 \\
\hline & & 1850 & DAŻO & F. 90, op. 1 , spr. 1157 \\
\hline & & 1856 & DAŻO & F. 90, op. 1 , spr. 1200 \\
\hline & & 1861 & DAŻO & F. 90 , op. 1, spr. 1226 \\
\hline & & 1871 & DAŻO & F. 90, op. 1 , spr. 1273 \\
\hline & & 1876 & DAŻO & F. 90 , op. 1 , spr. 1291 \\
\hline & & 1899 & DAŻO & F. 90, op. 1, spr. 1339 \\
\hline 72. & Nowosielica, dek. Płoskirów & 1888 & DAŻO & F. 90 , op. 1 , spr. 1320 \\
\hline \multirow{8}{*}{73.} & \multirow{8}{*}{$\begin{array}{l}\text { Nowogród Wołyński (Zwiahel), dek. } \\
\text { Nowogród Wołyński } \\
\text { (później dek. Równe) }\end{array}$} & pocz. XIX & CDIAU, Kijów & F. 1045 , op. 1, spr. 127 \\
\hline & & 1818 & CDIAU, Kijów & F. 1045 , op. 2 , spr. 298 \\
\hline & & 1820 & CDIAU, Kijów & F. 1045 , op. 1 , spr. 2 \\
\hline & & 1824 & CDIAU, Kijów & F. 1045 , op. 2 , spr. 299 \\
\hline & & 1839 & CDIAU, Kijów & F. 1045 , op. 2 , spr. 300 \\
\hline & & $1856-1861$ & DAŻO & F. 178, op. 51 , spr. 87 \\
\hline & & 1873 & CDIAU, Kijów & F. 1045, op. 2 , spr. 312 \\
\hline & & 1876 & CDIAU, Kijów & F. 1045 , op. 2 , spr. 314 \\
\hline \multirow{2}{*}{74.} & \multirow{2}{*}{ Olewsk, dek. Owrucz } & 1848 & DAŻO & F. 90, op. 1, spr. 1140 \\
\hline & & 1856 & DAŻO & F. 90 , op. 1 , spr. 1202 \\
\hline
\end{tabular}




\begin{tabular}{|c|c|c|c|c|}
\hline \multirow{11}{*}{75 . } & \multirow{11}{*}{ Ołyka, kolegiata; dek. Dubno } & 1802 & DAŻO & F. 90, op. 1, spr. 237 \\
\hline & & $1819-1820$ & DAŻO & $\begin{array}{l}\text { F. } 90 \text {, op. } 1 \text {, spr. } 400 ; 454 \text {; } \\
459\end{array}$ \\
\hline & & $1824-1827$ & DAŻO & $\begin{array}{l}\text { F. 90, op. } 1 \text {, spr. } 609 ; 658 ; \\
712 ; 764\end{array}$ \\
\hline & & 1831 & DAŻO & F. 90 , op. 1 , spr. 972 \\
\hline & & 1833 & DAŻO & F. 90 , op. 1 , spr. 1063 \\
\hline & & 1841 & DAŻO & F. 90, op. 1, spr. 1098 \\
\hline & & $1844-1845$ & DAŻO & F. 90, op. 1 , spr. $1127 ; 1134$ \\
\hline & & 1851 & DAŻO & F. 90, op. 1 , spr. $1169-1170$ \\
\hline & & 1861 & DAŻO & F. 90 , op. 1 , spr. 1227 \\
\hline & & 1866 & DAŻO & F. 90 , op. 1 , spr. 1254 \\
\hline & & 1871 & DAŻO & F. 90 , op. 1 , spr. 1275 \\
\hline \multirow{6}{*}{76.} & \multirow{6}{*}{ Opalin, dek. Kowel } & 1798-1799 & DAŻO & F. 90, op. 1, srp. 201; 219 \\
\hline & & 1810 & DAŻO & F. 90, op. 1, spr. 277 \\
\hline & & $1818-1820$ & DAŻO & $\begin{array}{l}\text { F. } 90 \text {, op. } 1 \text {, spr. } 352 ; 403 ; \\
457\end{array}$ \\
\hline & & $1822-1827$ & DAŻO & $\begin{array}{l}\text { F. } 90 \text {, op. } 1 \text {, spr. 506; 557; } \\
607 ; 657 ; 713 ; 766\end{array}$ \\
\hline & & $1829-1833$ & DAŻO & $\begin{array}{l}\text { F. 90, op. 1, spr. 868; 914; } \\
\text { 970; 1021; } 1061\end{array}$ \\
\hline & & 1856 & DAŻO & F. 90, op. 1, spr. 1201 \\
\hline 77. & Ostropol, dek. Zasław & 1807 & DAŻO & F. 90 , op. 1 , spr. 265 \\
\hline 78. & Ostrówek, dek. Kowel & 1799 & DAŻO & F. 90 , op. 1 , spr. 220 \\
\hline \multirow{9}{*}{79 . } & \multirow{9}{*}{ Ostróg, dek. Ostróg } & 1796 & CDIAU, Kijów & F. 1045 , op. 2 , spr. 356 \\
\hline & & 1799 & DAŻO & F. 90 , op. 1 , spr. 218 \\
\hline & & 1807 & DAŻO & F. 90 , op. 1 , spr. 264 \\
\hline & & $1818-1820$ & DAŻO & $\begin{array}{l}\text { F. } 90 \text {, op. } 1 \text {, spr. } 350 ; 402 \text {; } \\
458\end{array}$ \\
\hline & & 1822 & DAŻO & F. 90, op. 1 , spr. $505 ; 507$ \\
\hline & & $1823-1833$ & DAŻO & $\begin{array}{l}\text { F. } 90 \text {, op. } 1 \text {, spr. } 558 ; 608 ; \\
661 ; 711 ; 767 ; 816 ; 867 ; \\
917 ; 969 ; 1020 ; 1062\end{array}$ \\
\hline & & 1841 & DAŻO & F. 90 , op. 1 , spr. 1096 \\
\hline & & 1844 & DAŻO & F. 90 , op. 1 , spr. 1128 \\
\hline & & $1870-1871$ & DAŻO & F. 90 , op. 1 , spr. $1261 ; 1274$ \\
\hline \multirow{2}{*}{80.} & \multirow{2}{*}{ Pawołocz, dek. Skwira } & 1829 & DAŻO & F. 90 , op. 1 , spr. $869 ; 870$ \\
\hline & & 1888 & DAŻO & F. 90 , op. 1, spr. 1322 \\
\hline \multirow{2}{*}{81.} & \multirow{2}{*}{ Płoskirow, dek. Płoskirow } & $1796-1825$ & DAChO & F. 685 , op. 3 , spr. 2 \\
\hline & & 1888 & DAŻO & F. 90 , op. 1 , spr. 1321 \\
\hline \multirow{2}{*}{82.} & \multirow{2}{*}{$\begin{array}{l}\text { Pohrebyszcze, dek. Machnówka (póź- } \\
\text { niej Berdyczów) }\end{array}$} & 1819 & CDIAU, Kijów & F. 1046 , op. 1 , spr. 8 \\
\hline & & 1819 & DAŻO & F. 90, op. 1 , spr. 405 \\
\hline
\end{tabular}




\begin{tabular}{|c|c|c|c|c|}
\hline \multirow{5}{*}{83.} & \multirow{5}{*}{ Przewały, dek. Kowel } & 1799 & DAŻO & F. 90, op. 1, spr. 221 \\
\hline & & $1818-1820$ & DAŻO & $\begin{array}{l}\text { F. } 90 \text {, op. } 1 \text {, spr. } 353 ; 404 ; \\
460\end{array}$ \\
\hline & & $1822-1833$ & DAŻO & $\begin{array}{l}\text { F. } 90, \text { op. } 1 \text {, spr. } 510 ; 561 ; \\
610 ; 662 ; 715 ; 769 ; 819- \\
820 ; 871 ; 919 ; 973 ; 1022- \\
1023 ; 1064\end{array}$ \\
\hline & & 1856 & DAŻO & F. 90 , op. 1 , spr. 1204 \\
\hline & & 1899 & DAŻO & F. 90, op. 1 , spr. 1337 \\
\hline 84. & Przyłuka, dek. Berdyczów & 1831 & DAŻO & F. 90 , op. 1 , spr. 974 \\
\hline 85. & Pulin, dek. Żytomierz & 1799 & DAŻO & F. 90 , op. 1 , spr. 222 \\
\hline \multirow{5}{*}{86.} & \multirow{5}{*}{ Ratne, dek. Kowel } & 1799 & DAŻO & F. 90 , op. 1 , spr. 223 \\
\hline & & 1818 & DAŻO & F. 90 , op. 1, spr. 356 \\
\hline & & $1827-1833$ & DAŻO & $\begin{array}{l}\text { F. } 90, \text { op. } 1, \text { spr. } 772 ; 821 \\
872 ; 920 ; 977 ; 1024 ; 1065\end{array}$ \\
\hline & & 1843 & CDIAU, Kijów & F. 2227 , op. 1 , spr. 676 \\
\hline & & 1856 & DAŻO & F. 90, op. 1 , spr. 1206 \\
\hline 87. & $\begin{array}{l}\text { Rozjampol (Uściług), par. Korytnica; } \\
\text { dek. Włodzimierz }\end{array}$ & 1898 & DAŻO & F. 90 , op. 1 , spr. 1334 \\
\hline 88. & Rozważów, dek. Radomyśl & 1834 & CDIAU, Kijów & F. 1040 , op. 2 , spr. 478 \\
\hline \multirow{3}{*}{89.} & \multirow{3}{*}{ Równe, dek. Równe } & 1796 & CDIAU, Kijów & F. 1045 , op. 2 , spr. 356 \\
\hline & & 1849 & CDIAU, Kijów & F. 1045 , op. 2 , spr. 304 \\
\hline & & 1856 & DAŻO & F. 90, op. 1 , spr. 1205 \\
\hline 90. & Różyn, dek. Skwira & 1838 & CDIAU, Kijów & F. 1041 , op. 1 , spr. 11 \\
\hline 91. & Satanów, dek. Płoskirów & 1888 & DAŻO & F. 90, op. 1 , spr. 1324 \\
\hline 92. & Skazińce, dek. Płoskirów & 1888 & DAŻO & F. 90, op. 1, spr. 1323 \\
\hline \multirow{6}{*}{93.} & \multirow{6}{*}{ Skórcze, dek. Łuck } & 1807 & DAŻO & F. 90 , op. 1 , spr. 267 \\
\hline & & 1819 & DAŻO & F. 90 , op. 1 , spr. 409 \\
\hline & & $1822-1824$ & DAŻO & $\begin{array}{l}\text { F. } 90, \text { op. } 1 \text {, spr. } 513 ; 565 ; \\
612\end{array}$ \\
\hline & & $1826-1833$ & DAŻO & $\begin{array}{l}\text { F. } 90, \text { op. 1, spr. 719; 774; } \\
823 ; 875 ; 927 ; 981 ; 1026 \text {; } \\
1068\end{array}$ \\
\hline & & 1845 & DAŻO & F. 90 , op. 1 , spr. 1135 \\
\hline & & 1851 & DAŻO & F. 90, op. 1 , spr. $1172-1173$ \\
\hline 94. & Skuraty, dek. Radomyśl & 1831 & CDIAU, Kijów & F. 1040 , op. 1 , spr. 19 \\
\hline 95. & Smiła, dek. Zwinogródka & 1825 & DAŻO & F. 90 , op. 1 , spr. 665 \\
\hline 96. & Sokołówka, kapl. & 1819 & DAŻO & F. 90 , op. 1 , spr. 410 \\
\hline \multirow{9}{*}{97.} & \multirow{9}{*}{ Sokul, dek. Łuck } & 1801 & DAŻO & F. 90 , op. 1 , spr. 235 \\
\hline & & 1807 & DAŻO & F. 90 , op. 1 , spr. 268 \\
\hline & & $1818-1820$ & DAŻO & $\begin{array}{l}\text { F. } 90 \text {, op. } 1 \text {, spr. } 358 ; 407 ; \\
463\end{array}$ \\
\hline & & $1823-1833$ & DAŻO & $\begin{array}{l}\text { F. } 90, \text { op. } 1 \text {, spr. } 563 ; 613 \\
664 ; 717 ; 775 ; 825 ; 876 ; \\
928 ; 978 ; 1025 ; 1066\end{array}$ \\
\hline & & 1841 & DAŻO & F. 90, op. 1, spr. 1099 \\
\hline & & 1850 & DAŻO & F. 90, op. 1 , spr. 1159 \\
\hline & & 1851 & DAŻO & F. 90 , op. 1 , spr. 1174 \\
\hline & & 1888 & DAŻO & F. 90 , op. 1 spr. 1325 \\
\hline & & 1918 & DAWO, Łuck & F. 35 , op. 1 , spr. 468 \\
\hline
\end{tabular}




\begin{tabular}{|c|c|c|c|c|}
\hline \multirow{2}{*}{98.} & \multirow{2}{*}{ Sokulec, dek. Uszyca } & 1865 & DAŻO & F. 90 , op. 1, spr. 1238 \\
\hline & & 1909 & DAŻO & F. 178 , op. 1 , spr. 263 \\
\hline 99. & Stawiszcze, dek. Humań & 1847 & DAŻO & F. 90, op. 1, spr. 1139 \\
\hline \multirow{2}{*}{100.} & \multirow{2}{*}{ Stepań, dek. Równe } & 1799 & DAŻO & F. 90 , op. 1 , spr. 224 \\
\hline & & 1849 & CDIAU, Kijów & F. 1045 , op. 2, spr. 303 \\
\hline \multirow{3}{*}{101.} & \multirow{3}{*}{ Swojczów, dek. Włodzimierz } & $1818-1820$ & DAŻO & $\begin{array}{l}\text { F. } 90 \text {, op. } 1 \text {, spr. } 357 ; 408 ; \\
462\end{array}$ \\
\hline & & $1822-1833$ & DAŻO & $\begin{array}{l}\text { F. 90, op. 1, spr. 512; 564; } \\
611 ; 666 ; 718 ; 773 ; 824 ; \\
874 ; 926 ; 980 ; 1027 ; 1067\end{array}$ \\
\hline & & 1866 & DAŻO & F. 90 , op. 1 , spr. 1255 \\
\hline 102. & Szarawka, dek. Płoskirów & 1888 & DAŻO & F. 90 , op. 1 , spr. 1330 \\
\hline 103. & Szpanów, dek. Równe & 1807 & DAŻO & F. 90 , op. 1 , spr. 272 \\
\hline \multirow{7}{*}{104.} & \multirow{7}{*}{ Szumsk, dek. Krzemieniec } & 1851 & DAŻO & F. 90 , op. 1, spr. 1175 \\
\hline & & 1856 & DAŻO & F. 90 , op. 1, spr. 1208 \\
\hline & & 1860 & DAŻO & F. 90 , op. 1 , spr. 1218 \\
\hline & & 1861 & DAŻO & F. 90, op. 1, spr. 1229 \\
\hline & & 1866 & DAŻO & F. 90 , op. 1 , spr. 1256 \\
\hline & & 1871 & DAŻO & F. 90, op. 1, spr. 1277 \\
\hline & & 1876 & DAŻO & F. 90, op. 1, spr. 1294 \\
\hline 105. & Tajgury, dek. Ostróg & 1799 & DAŻO & F. 90 , op. 1 , spr. 226 \\
\hline 106. & Tarnoruda, dek. Płoskirów & 1888 & DAŻO & F. 90 , op. 1 , spr. 1326 \\
\hline 107. & Toporzyszcze, dek. Owrucz & 1888 & DAŻO & F. 90, op. 1, spr. 1327 \\
\hline 108. & Topory, dek. Skwira & 1832 & DAŻO & F. 90, op. 1, spr. 1029 \\
\hline \multirow{8}{*}{109.} & \multirow{8}{*}{ Torczyn, dek. Łuck } & 1807 & DAŻO & F. 90, op. 1, spr. 270 \\
\hline & & 1818 & DAŻO & F. 90 , op. 1 , spr. $360-361$ \\
\hline & & 1819 & DAŻO & F. 90 , op. 1, spr. 413-414 \\
\hline & & 1820 & DAŻO & F. 90 , op. 1 , spr. 466 \\
\hline & & $1822-1833$ & DAŻO & $\begin{array}{l}\text { F. } 90 \text {, op. } 1 \text {, spr. } 515 ; 568 ; \\
615 ; 669 ; 720 ; 777 ; 828 ; \\
877 ; 930 ; 983 ; 1028 ; 1070\end{array}$ \\
\hline & & 1842 & DAŻO & F. 90 , op. 1, spr. 1113 \\
\hline & & 1850 & DAŻO & F. 90 , op. 1 , spr. 1160 \\
\hline & & 1856 & DAŻO & F. 90, op. 1, spr. 1207 \\
\hline \multirow{12}{*}{110.} & \multirow{12}{*}{ Tuczyn, dek. Równe } & $1818-1820$ & DAŻO & $\begin{array}{l}\text { F. } 90 \text {, op. } 1 \text {, spr. } 359 ; 411 ; \\
465\end{array}$ \\
\hline & & $1822-1828$ & DAŻO & $\begin{array}{l}\text { F. 90, op. } 1, \text { spr. } 514 ; 566 ; \\
614 ; 668 ; 721 ; 776 ; 827\end{array}$ \\
\hline & & $1830-1831$ & DAŻO & F. 90 , op. 1 , spr. $929 ; 982$ \\
\hline & & 1833 & DAŻO & F. 90, op. 1, spr. 1069 \\
\hline & & $1841-1842$ & DAŻO & F. 90, op. 1 , spr. $1100 ; 1112$ \\
\hline & & 1849 & CDIAU, Kijów & F. 1045 , op. 1, spr. 9 \\
\hline & & 1850 & DAŻO & F. 90, op. 1, spr. 1161 \\
\hline & & 1855 & DAŻO & F. 90 , op. 1 , spr. 1185 \\
\hline & & 1861 & DAŻO & F. 90 , op. 1 , spr. 1228 \\
\hline & & 1863 & DAŻO & F. 90, op. 1, spr. 1233 \\
\hline & & 1871 & DAŻO & F. 90, op. 1, spr. 1276 \\
\hline & & 1876 & DAŻO & F. 90, op. 1, spr. 1292 \\
\hline
\end{tabular}




\begin{tabular}{|c|c|c|c|c|}
\hline \multirow{2}{*}{111.} & \multirow{2}{*}{ Turzysk, dek. Kowel } & 1840 & DAŻO & F. 90, op. 1 , spr. 1080 \\
\hline & & 1899 & DAŻO & F. 90 , op. 1 , spr. 1338 \\
\hline 112. & Tynna, dek. Uszyca & 1877 & DAŻO & F. 90 , op. 1 spr. 1296 \\
\hline 113. & Wczorajsze, dek. Skwira & 1889 & DAŻO & F. 90, op. 1 , spr. 1332 \\
\hline \multirow{7}{*}{114.} & \multirow{7}{*}{ Wiszenki, dek. Łuck } & 1807 & DAŻO & F. 90 , op. 1 , spr. 250 \\
\hline & & $1818-1820$ & DAŻO & $\begin{array}{l}\text { F. } 90 \text {, op. } 1 \text {, spr. } 315 ; 371 \text {; } \\
423\end{array}$ \\
\hline & & $1822-1828$ & DAŻO & $\begin{array}{l}\text { F. } 90 \text {, op. } 1, \text { spr. } 473 ; 527 ; \\
574 ; 626 ; 680 ; 733 ; 785\end{array}$ \\
\hline & & 1830 & DAŻO & F. 90 , op. 1 , spr. 886 \\
\hline & & $1832-1833$ & DAŻO & F. 90, op. 1 , spr. 994; 1036 \\
\hline & & 1841 & DAŻO & F. 90, op. 1 , spr. 1083 \\
\hline & & 1850 & DAŻO & F. 90 , op. 1 , spr. 1147 \\
\hline 115. & Wiśniowiec, dek. Krzemieniec & 1816 & DAŻO & F. 90 , op. 1 , spr. 287 \\
\hline 116. & Włodzimierz Wołyński & 1850 & DAŻO & F. 90 , op. 1 , spr. 1148 \\
\hline 117. & Włodzimierzec, dek. Łuck & 1807 & DAŻO & F. 90 , op. 2 , spr. 6 \\
\hline 118. & Wońkowce, dek. Uszyca & 1909 & DAŻO & F. 178, op. 1 , spr. 263 \\
\hline \multirow{8}{*}{119.} & \multirow{8}{*}{ Wyżgródek, dek. Krzemieniec } & 1807 & DAŻO & F. 90 , op. 1 , spr. 249 \\
\hline & & $1819-1820$ & DAŻO & F. 90 , op. 1 , spr. $369 ; 424$ \\
\hline & & $1822-1833$ & DAŻO & $\begin{array}{l}\text { F. 90, op. } 1 \text {, spr. } 475 ; 525 \text {; } \\
575 ; 625 ; 678 ; 732 ; 786 \text {; } \\
836 ; 887 ; 941 ; 993 ; 1037\end{array}$ \\
\hline & & 1860 & DAŻO & F. 90, op. 1 , spr. 1213 \\
\hline & & 1861 & DAŻO & F. 90, op. 1 , spr. 1222 \\
\hline & & 1866 & DAŻO & F. 90 , op. 1 , spr. 1244 \\
\hline & & 1871 & DAŻO & F. 90, op. 1 , spr. 1264 \\
\hline & & 1881 & DAŻO & F. 90, op. 1, spr. 1297 \\
\hline 120. & Uszomierz, dek. Żytomierz & $\begin{array}{c}1842,1844 \\
1846\end{array}$ & CDIAU, Kijów & F. 1045 , op. 2 , spr. 301 \\
\hline \multirow{9}{*}{121.} & \multirow{9}{*}{ Zabłotce, dek. Włodzimierz } & 1801 & DAŻO & F. 90 , op. 1 , spr. 229 \\
\hline & & 1818 & DAŻO & F. 90 , op. 1 , spr. 325 \\
\hline & & 1820 & DAŻO & F. 90 , op. 1 , spr. 433 \\
\hline & & $1822-1823$ & DAŻO & F. 90, op. 1 , spr. $484 ; 536$ \\
\hline & & $1825-1826$ & DAŻO & F. 90, op. 1 , spr. $641 ; 686$ \\
\hline & & 1827 & DAŻO & F. 90, op. 1, spr. $740 ; 743$ \\
\hline & & $1828-1833$ & DAŻO & $\begin{array}{l}\text { F. 90, op. 1, spr. 793; 844; } \\
896 ; 948 ; 1000 ; 1042\end{array}$ \\
\hline & & 1856 & DAŻO & F. 90 , op. 1 , spr. 1190 \\
\hline & & 1866 & DAŻO & F. 90, op. 1 , spr. 1245 \\
\hline 122. & Zaturce, dek. Włodzimierz & 1866 & DAŻO & F. 90 , op. 1 , spr. 1246 \\
\hline 123. & $\begin{array}{l}\text { Zawadówka, par. Wołodarka, } \\
\text { dek. Skwira }\end{array}$ & 1830 & CDIAU, Kijów & F. 1041 , op. 1 , spr. 4 \\
\hline \multirow{2}{*}{124.} & \multirow{2}{*}{ Zawalijka, dek. Płoskirow } & 1888 & DAŻO & F. 90, op. 1, spr. 1317 \\
\hline & & 1909 & DAŻO & F. 178, op. 1 , spr. 263 \\
\hline
\end{tabular}




\begin{tabular}{|c|c|c|c|c|}
\hline \multirow{10}{*}{125 . } & \multirow{10}{*}{ Złoczówka, dek. Dubno } & 1799 & DAŻO & F. 90 , op. 1, spr. 205 \\
\hline & & $1818-1820$ & DAŻO & $\begin{array}{l}\text { F. } 90 \text {, op. } 1 \text {, spr. } 324 ; 384 ; \\
431\end{array}$ \\
\hline & & $1822-1833$ & DAŻO & $\begin{array}{l}\text { F. } 90, \text { op. } 1 \text {, spr. 482; 535; } \\
584 ; 636 ; 688 ; 741 ; 795 \text {; } \\
845 ; 894 ; 946 ; 1001 ; 1043\end{array}$ \\
\hline & & $1841-1842$ & DAŻO & F. 90, op. 1, spr.1088; 1106 \\
\hline & & $1844-1845$ & DAŻO & F. 90 , op. 1 , spr. $1124 ; 1130$ \\
\hline & & 1850 & DAŻO & F. 90 , op. 1 , spr. 1151 \\
\hline & & 1855 & DAŻO & F. 90 , op. 1 , spr. 1180 \\
\hline & & 1860 & DAŻO & F. 90 , op. 1 , spr. 1214 \\
\hline & & 1865 & DAŻO & F. 90 , op. 1 , spr. 1235 \\
\hline & & 1870 & DAŻO & F. 90, op. 1, spr. 1259 \\
\hline 126. & Zozów, dek. Berdyczów & 1820 & DAŻO & F. 90 , op. 1, spr. 433a \\
\hline \multirow{10}{*}{127.} & \multirow{10}{*}{ Żytomierz, katedra } & 1799 & DAŻO & F. 178 , op. 51 , spr. 10 \\
\hline & & 1802 & DAŻO & F. 90 , op. 1, spr. 239 \\
\hline & & 1809 & DAŻO & F. 90, op. 1, spr. 276a \\
\hline & & 1818 & DAŻO & F. 178 , op. 51 , spr. 20 \\
\hline & & 1819 & DAŻO & F. 90 , op. 1, spr. 385 \\
\hline & & 1821 & DAŻO & $\begin{array}{l}\text { F. } 90, \text { op. } 1, \text { spr. } 467 ; \\
\text { F. } 178 \text {, op. } 51, \text { spr. } 33\end{array}$ \\
\hline & & $1827-1829$ & DAŻO & $\begin{array}{l}\text { F. } 178, \text { op. } 51, \text { spr. } 48 ; 54 ; \\
57\end{array}$ \\
\hline & & 1832 & DAŻO & $\begin{array}{l}\text { F. } 178, \text { op. } 51, \text { spr. } 65 \\
\text { F. } 90 \text {, op. } 1, \text { spr. } 1002\end{array}$ \\
\hline & & 1834 & DAŻO & F. 178 , op. 51 , spr. 68 \\
\hline & & 1856 & DAŻO & F. 178 , op. 51 , spr. 86 \\
\hline \multirow{3}{*}{$128 .}$. & \multirow{3}{*}{ Żytomierz, seminarium } & 1799 & DAŻO & F 178, op. 51, spr. 9 \\
\hline & & 1830 & CDIAU, Kijów & F. 1044 , op. 1 , spr. 30 \\
\hline & & 1870 & CDIAU, Kijów & F. 1044 , op. 1, spr. 32 \\
\hline 129. & Nieustalona parafia & 1807 & DAŻO & F. 90 , op. 1 , spr. 266 \\
\hline 130. & Nieustalona parafia & 1819 & DAŻO & F. 90 , op. 1 , spr. 372 \\
\hline \multicolumn{2}{|c|}{ Ogółem } & 1796-1918 & \multicolumn{2}{|r|}{875 Poszytów } \\
\hline & Klasztory & Lata & Archiwum & Sygnatura \\
\hline \multicolumn{5}{|c|}{ Klasztory męskie } \\
\hline \multicolumn{5}{|c|}{ Augustianie } \\
\hline \multirow{4}{*}{1.} & \multirow{4}{*}{ Kodnia } & 1805 & DAŻO & F. 90 , op. 1, srp. 242 \\
\hline & & 1817 & DAŻO & F. 90 , op. 1, spr. 303 \\
\hline & & 1818 & DAŻO & F. 178 , op. 51 , spr. 21 \\
\hline & & 1828 & DAŻO & F. 90 , op. 1 , spr. 806 \\
\hline \multirow{3}{*}{2.} & \multirow{3}{*}{ Radziechów } & $1817-1820$ & DAŻO & $\begin{array}{l}\text { F. } 90, \text { op. } 1 \text {, spr. } 309 ; 355 ; \\
406 ; 461\end{array}$ \\
\hline & & $1822-1823$ & DAŻO & F. 90 , op. 1 , spr. $511 ; 562$ \\
\hline & & $1825-1831$ & DAŻO & $\begin{array}{l}\text { F. } 90 \text {, op. } 1 \text {, spr. } 663 ; 716 \text {; } \\
771 ; 822 ; 873 ; 921 ; 976\end{array}$ \\
\hline
\end{tabular}




\begin{tabular}{|c|c|c|c|c|}
\hline \multirow[b]{2}{*}{3.} & \multirow[b]{2}{*}{ Zaturce } & $1817-1820$ & DAŻO & $\begin{array}{l}\text { F. 90, op. 1, spr. } 301 ; 326 ; \\
382 ; 432\end{array}$ \\
\hline & & $1822-1831$ & DAŻO & $\begin{array}{l}\text { F. } 90 \text {, op. } 1 \text {, spr. 483; 534; } \\
583 ; 635 ; 687 ; 742 ; 794 \text {; } \\
846 ; 895 ; 947\end{array}$ \\
\hline \multicolumn{5}{|c|}{ Bernardyni } \\
\hline \multirow{4}{*}{4.} & \multirow{4}{*}{ Cudnów } & $1792-1804$ & CDIAU, Kijów & F. 1044 , op. 1 , spr. 36 \\
\hline & & 1817 & DAŻO & F. 90, op. 1, spr. 310a \\
\hline & & 1825 & DAŻO & F. 178 , op. 51 , spr. 43 \\
\hline & & 1827 & DAŻO & F. 178 , op. 51 , spr. 49 \\
\hline \multirow{4}{*}{5.} & \multirow{4}{*}{ Dubno } & $1817-1820$ & DAŻO & $\begin{array}{l}\text { F. } 90 \text {, op. } 1 \text {, spr. } 300 ; 319, \\
323 ; 378-379 ; 428\end{array}$ \\
\hline & & $1822-1833$ & DAŻO & $\begin{array}{l}\text { F. 90, op. 1, spr. 478; 530; } \\
578 ; 630,633 ; 685 ; 739 \text {; } \\
789 ; 843 ; 893 ; 943 ; 998 \text {; } \\
1041\end{array}$ \\
\hline & & 1842 & DAŻO & F. 90 , op. 1 , spr. 1105 \\
\hline & & 1851 & DAŻO & F. 90 , op. 1 , spr. 1171 \\
\hline 6. & $\begin{array}{l}\text { Janów } \\
\text { Jarmolińce }\end{array}$ & $\begin{array}{l}1799-1820 \\
1801-1817\end{array}$ & DAWinO & F. 737 , op. 1 , spr. 3 \\
\hline \multirow{4}{*}{7.} & \multirow{4}{*}{ Janów } & 1801 & DAŻO & F. 90 , op. 1, spr. 236 \\
\hline & & $1817-1819$ & DAŻO & $\begin{array}{l}\text { F. } 90 \text {, op. } 1 \text {, spr. } 310 ; 363 ; \\
416\end{array}$ \\
\hline & & $1822-1831$ & DAŻO & $\begin{array}{l}\text { F. } 90, \text { op. } 1 \text {, spr. 518; 569; } \\
620 ; 667 ; 725 ; 778 ; 829 ; \\
878,934 ; 986\end{array}$ \\
\hline & & 1829 & DAChO & F. 685 , op. 4 , spr. 30 \\
\hline \multirow{3}{*}{8.} & \multirow{3}{*}{ Łuck } & 1832 & DAŻO & F. 90, op. 1, spr. 1011 \\
\hline & & 1850 & DAŻO & F. 90 , op. 1 , spr. 1155 \\
\hline & & 1851 & DAŻO & F. 90 , op. 1 , spr. 1167 \\
\hline \multirow{3}{*}{9.} & \multirow{3}{*}{ Warkowicze } & 1817 & DAŻO & F. 90 , op. 1, spr. $295-296$ \\
\hline & & $1818-1820$ & DAŻO & $\begin{array}{l}\text { F. } 90 \text {, op. } 1 \text {, spr. } 316 ; 370 \text {; } \\
425\end{array}$ \\
\hline & & $1822-1831$ & DAŻO & $\begin{array}{l}\text { F. } 90, \text { op. } 1, \text { spr. 474; 524; } \\
576 ; 627 ; 679 ; 731 ; 784 ; \\
837 ; 888 ; 940\end{array}$ \\
\hline \multicolumn{5}{|c|}{ Bonifratrzy } \\
\hline \multirow{4}{*}{10.} & \multirow{4}{*}{ Łuck } & 1796 & DAŻO & F. 90, op. 1, spr. $213 \mathrm{~b}$ \\
\hline & & $1804(1818)$ & DAŻO & $\begin{array}{l}\begin{array}{l}\text { F. 90, op. 1, spr. } 278 \\
\text { [fragm.] }\end{array} \\
\end{array}$ \\
\hline & & $1818-1820$ & DAŻO & $\begin{array}{l}\text { F. } 90 \text {, op. } 1 \text {, spr. } 337 ; 394 ; \\
447\end{array}$ \\
\hline & & $\begin{array}{c}1822-1831 \\
1833 \\
\end{array}$ & DAŻO & $\begin{array}{l}\text { F. } 90, \text { op. } 1 \text {, spr. } 470 ; 550 ; \\
595 ; 650 ; 702 ; 755 ; 811 ; \\
858 ; 906 ; 963 ; 1054\end{array}$ \\
\hline \multirow[b]{3}{*}{11.} & & Dominikani & & \\
\hline & \multirow{2}{*}{$\begin{array}{l}\text { Podole: [Bar, Kamieniec Podolski, } \\
\text { Latyczów, Murafa, Smotrycz, Sołob- } \\
\text { kowce, Sokolec, Szarawka, Tulczyn, } \\
\text { Tywrów, Winnica] }\end{array}$} & $1823-1824$ & DAChO & F. 685 , op. 4 , spr. 21 \\
\hline & & 1824 & DAChO & F. 685 , op. 4 , spr. 23 \\
\hline
\end{tabular}




\begin{tabular}{|c|c|c|c|c|}
\hline \multirow{5}{*}{12.} & \multirow{5}{*}{ Kamień Koszyrski } & 1806 & DAŻO & F. 90 , op. 1, spr. 244 \\
\hline & & $1817-1818$ & DAŻO & F. 90 , op. 1 , spr. $302 ; 329$ \\
\hline & & 1820 & DAŻO & F. 90 , op. 1 , spr. 444 \\
\hline & & $1822-1824$ & DAŻO & $\begin{array}{l}\text { F. } 90 \text {, op. } 1 \text {, spr. } 492 ; 537- \\
538 ; 586\end{array}$ \\
\hline & & $1826-1831$ & DAŻO & $\begin{array}{l}\text { F. } 90, \text { op. } 1 \text {, spr. } 698 ; 747 \text {; } \\
797 ; 854 ; 900 ; 956\end{array}$ \\
\hline 13. & Kozin & 1822 & DAŻO & F. 90 , op. 1 , spr. 495 \\
\hline \multirow{11}{*}{14.} & \multirow{11}{*}{ Lachowce } & pocz. XIX & DAŻO & $\begin{array}{l}\text { F. } 90 \text {, op. } 1 \text {, spr. } 336, \text { k. } 6- \\
28\end{array}$ \\
\hline & & 1807 & DAŻO & F. 90 , op. 1 , spr. $257-258$ \\
\hline & & 1817 & DAŻO & F. 90 , op. 1 , spr. 304 \\
\hline & & 1820 & DAŻO & F. 90 , op. 1 , spr. 448 \\
\hline & & $1822-1830$ & DAŻO & $\begin{array}{l}\text { F. } 90 \text {, op. } 1 \text {, spr. 497; 549, } \\
551 ; 597 ; 648 ; 704 ; 757 \text {; } \\
810 ; 860-861 ; 911\end{array}$ \\
\hline & & 1833 & DAŻO & F. 90 , op. 1 , spr. 1052 \\
\hline & & 1837 & DAŻO & F. 90 , op. 1 , spr. 1072 \\
\hline & & 1841 & DAŻO & F. 90 , op. 1 , spr. 1092 \\
\hline & & 1843 & DAŻO & F. 90, op. 1 , spr. $1116-1117$ \\
\hline & & 1847 & DAŻO & F. 90 , op. 1 , spr. 1138 \\
\hline & & 1849 & DAŻO & F. 90 , op. 1 , spr. 1141 \\
\hline \multirow{2}{*}{15 . } & \multirow{2}{*}{ Lubar } & 1820 & DAŻO & F. 178, op. 51 , spr. 32 \\
\hline & & $1836-1837$ & DAŻO & F. 178 , op. 51, spr. 70,72 \\
\hline \multirow[b]{2}{*}{16.} & \multirow[b]{2}{*}{ Łuck } & 1831 & DAŻO & F. 90 , op. 1, spr. 962 \\
\hline & & 1832 & DAŻO & $\begin{array}{l}\text { F. 90, op. 1, spr. 1009- } \\
1010\end{array}$ \\
\hline 17. & Murafa & 1844 & DAChO & F. 689 , op. 1 , spr. 80 \\
\hline \multirow{3}{*}{18.} & \multirow{3}{*}{ Niewirków } & 1816 & DAŻO & F. 90 , op. 1 , spr. $289-290$ \\
\hline & & $1818-1820$ & DAŻO & $\begin{array}{l}\text { F. } 90 \text {, op. } 1 \text {, spr. } 347 ; 377 \text {, } \\
399 ; 451\end{array}$ \\
\hline & & $1822-1832$ & DAŻO & $\begin{array}{l}\text { F. } 90 \text {, op. } 1 \text {, spr. 503; 556; } \\
603 ; 655 ; 706-707 ; 762 \text {; } \\
815 ; 866 ; 923 ; 967 ; 1016\end{array}$ \\
\hline \multirow{4}{*}{19.} & \multirow{4}{*}{ Owrucz } & 1805 & DAŻO & F. 90 , op. 1 , spr. $243 \mathrm{a}$ \\
\hline & & 1807 & DAŻO & F. 90 , op. 1, spr. 263 \\
\hline & & 1821 & DAŻO & F. 90 , op. 1 , spr. $467 \mathrm{a}$ \\
\hline & & 1822 & DAŻO & F. 90 , op. 2 , spr. 9 \\
\hline \multicolumn{5}{|c|}{ Franciszkanie } \\
\hline \multirow{2}{*}{20.} & \multirow{2}{*}{$\begin{array}{l}\text { Podole: [Wońkowce, Bar, Komargród, } \\
\text { Gródek] }\end{array}$} & 1824 & $\mathrm{DAChO}$ & F. 685 , op. 4 , spr. 22 \\
\hline & & $1829-1830$ & DAChO & F. 685 , op. 4 , spr. 30 \\
\hline 21. & Iwnica & 1818 & DAŻO & F. 90 , op. 1, spr. 327 \\
\hline \multirow[b]{2}{*}{22.} & \multirow[b]{2}{*}{ Krzemieniec } & $1818-1820$ & DAŻO & $\begin{array}{l}\text { F. } 90 \text {, op. } 1 \text {, spr. } 334 ; 393 \text {; } \\
436,443\end{array}$ \\
\hline & & $1822-1831$ & DAŻO & $\begin{array}{l}\text { F. } 90 \text {, op. } 1 \text {, spr. 485-486; } \\
544 ; 593 ; 639 ; 697 ; 744 \text {; } \\
801 ; 851 ; 898 ; 950\end{array}$ \\
\hline
\end{tabular}




\begin{tabular}{|c|c|c|c|c|}
\hline \multirow{5}{*}{23.} & \multirow{5}{*}{ Międzyrzec Ostrogski } & 1804 & DAŻO & F. 90, op. 1, spr. 241 \\
\hline & & $1817-1820$ & DAŻO & $\begin{array}{l}\text { F. } 90 \text {, op. } 1 \text {, spr. } 305 ; 344- \\
345 ; 396 ; 450\end{array}$ \\
\hline & & $1823-1832$ & DAŻO & $\begin{array}{l}\text { F. } 90 \text {, op. } 1 \text {, spr. } 552 ; 600 \text {; } \\
653 ; 705 ; 759 ; 813 ; 862 \text {; } \\
913 ; 964 a ; 1015\end{array}$ \\
\hline & & 1843 & DAŻO & F. 90, op. 1 , spr. 1118 \\
\hline & & 1850 & DAŻO & F. 90, op. 1, spr. 1162 \\
\hline \multirow{5}{*}{24.} & \multirow{5}{*}{ Szumsk } & 1807 & DAŻO & F. 90, op. 1, spr. 273 \\
\hline & & $1818-1819$ & DAŻO & F. 90, op. 1, spr. $362 ; 415$ \\
\hline & & 1822 & DAŻO & F. 90, op. 1, spr. 517 \\
\hline & & 1824 & DAŻO & $\begin{array}{l}\text { F. } 90 \text {, op. } 1 \text {, spr. } 618-619 ; \\
672 ; 724\end{array}$ \\
\hline & & $1830-1831$ & DAŻO & F. 90, op. 1, spr. $933 ; 985$ \\
\hline \multicolumn{5}{|c|}{ Kapucyni } \\
\hline \multirow{3}{*}{25.} & \multirow{3}{*}{$\begin{array}{l}\text { Podole: [Dunajowce, Zbryż, } \\
\text { Kuna } \\
\text { Winnica] }\end{array}$} & $\begin{array}{l}1802-1820 \\
1799-1820 \\
1799-1817\end{array}$ & DAWinO & F. 737 , op. 1 , spr. 3 \\
\hline & & 1824 & DAChO & F. 685 , op. 4 , spr. 22 \\
\hline & & $1829-1830$ & DAChO & F. 685, op. 4 , spr. 30 \\
\hline \multirow{2}{*}{26.} & \multirow{2}{*}{ Brusiłów } & 1816 & DAŻO & F. 90 , op. 1 , spr. 285 \\
\hline & & 1850 & DAŻO & F. 178, op. 51, spr. 83 \\
\hline \multirow{2}{*}{27.} & \multirow{2}{*}{ Chodorków } & 1846 & CDIAU, Kijów & F. 1041 , op. 1 , spr. 76 \\
\hline & & 1876 & DAŻO & F. 90 , op. 1, spr. 1293 \\
\hline \multirow{4}{*}{28.} & \multirow{4}{*}{ Ostróg } & $1817-1820$ & DAŻO & $\begin{array}{l}\text { F. } 90 \text {, op. } 1 \text {, spr. } 306 ; 348- \\
349 ; 401 ; 455-456\end{array}$ \\
\hline & & $1822-1828$ & DAŻO & $\begin{array}{l}\text { F. } 90 \text {, op. } 1 \text {, spr. 508-509; } \\
560 ; 605-606 ; 659-660 ; \\
710 ; 765,768 ; 817-818\end{array}$ \\
\hline & & 1830 & DAŻO & $\begin{array}{l}\text { F. } 90 \text {, op. 1, spr. 915-916, } \\
918\end{array}$ \\
\hline & & 1831 & DAŻO & F. 90 , op. 1 , spr. 971 \\
\hline \multirow{4}{*}{29.} & \multirow{4}{*}{ Rozjampol [Uściług] } & $1816-1818$ & DAŻO & $\begin{array}{l}\text { F. } 90 \text {, op. } 1 \text {, spr. } 291 ; 307- \\
308 ; 354\end{array}$ \\
\hline & & 1822 & DAŻO & F. 90 , op. 1 , spr. 516a \\
\hline & & $1824-1827$ & DAŻO & $\begin{array}{l}\text { F. } 90 \text {, op. } 1 \text {, spr. } 617 ; 670- \\
671 ; 722 ; 770\end{array}$ \\
\hline & & $1829-1831$ & DAŻO & $\begin{array}{l}\text { F. } 90 \text {, op. } 1 \text {, spr. } 879 ; 922 ; \\
984\end{array}$ \\
\hline \multirow{5}{*}{30.} & \multirow{5}{*}{ Stary Konstantynów } & 1817 & DAŻO & F. 178, op. 52, spr. [8] \\
\hline & & 1820 & DAŻO & F. 178, op. 52 , spr. [10] \\
\hline & & 1822 & DAŻO & F. 178 , op. 52 , spr. [11] \\
\hline & & 1830 & DAŻO & F. 178, op. 52, spr. [19] \\
\hline & & 1850 & DAŻO & F. 178 , op. 52 , spr. 8 \\
\hline 31. & Winnica & 1844 & DAŻO & F. 90, op. 1 , spr. 1122 \\
\hline \multicolumn{5}{|c|}{ Karmelici bosi } \\
\hline 32. & $\begin{array}{l}\text { Wołyń: } \\
\text { [Berdyczów i Wiśniowiec] }\end{array}$ & $\begin{array}{c}1799 \\
1804-1805\end{array}$ & DAŻO & F. 90, op. 1 , spr. $213 \mathrm{a}$ \\
\hline
\end{tabular}




\begin{tabular}{|c|c|c|c|c|}
\hline \multirow{2}{*}{33.} & \multirow{2}{*}{$\begin{array}{l}\text { Podole: } \\
\text { [Kamieniec Podolski i Kupin] }\end{array}$} & 1824 & DAChO & F. 685 , op. 4 , spr. 22 \\
\hline & & $1829-1830$ & DAChO & F. 685 , op. 4 , spr. 30 \\
\hline \multicolumn{5}{|c|}{ Karmelici trzewiczkowi } \\
\hline 34. & $\begin{array}{l}\text { Wołyń: [Annopol, Dorohostaje, Horo- } \\
\text { dyszcze, Kisielin, Łabuń, Łuck, } \\
\text { Olewsk, Ostróg, Uszomierz, Topo- } \\
\text { rzyszcze] }\end{array}$ & $\begin{array}{c}1799 \\
1804-1805\end{array}$ & DAŻO & F. 90 , op. 1 , spr. $213 \mathrm{a}$ \\
\hline \multirow[b]{2}{*}{35.} & \multirow[b]{2}{*}{ Dorohostaje } & $1817-1820$ & DAŻO & $\begin{array}{l}\text { F. } 90, \text { op. } 1 \text {, spr. } 298 ; 321 ; \\
376 ; 430\end{array}$ \\
\hline & & $1822-1831$ & DAŻO & $\begin{array}{l}\text { F. } 90, \text { op. } 1 \text {, spr. 481; 533; } \\
581 ; 632 ; 683 ; 737 ; 791 ; \\
841 ; 890 ; 944\end{array}$ \\
\hline 36. & Horodyszcze & $1818-1819$ & DAŻO & F. 178 , op. 51 , spr. $19 ; 26$ \\
\hline \multirow{3}{*}{37.} & \multirow{3}{*}{ Olewsk } & 1807 & DAŻO & F. 90 , op. 1 , spr. $261-262$ \\
\hline & & 1815 & DAŻO & F. 90 , op. 1 , spr. 283 \\
\hline & & 1818 & DAŻO & F. 90, op. 1, spr. 351 \\
\hline \multirow{3}{*}{38.} & \multirow{3}{*}{ Toporzyszcze } & 1807 & DAŻO & F. 90 , op. 1 , spr. 269 \\
\hline & & 1815 & DAŻO & F. 90 , op. 1 , spr. 284 \\
\hline & & 1820 & DAŻO & F. 90 , op. 1 , spr. 464 \\
\hline 39. & Uszomierz & 1807 & DAŻO & F. 90, op. 1, spr. 271 \\
\hline \multicolumn{5}{|c|}{ Marianie } \\
\hline 40. & Berezdów & 1799,1804 & DAŻO & F. 90, op. 1 , spr. $213 b$ \\
\hline \multicolumn{5}{|c|}{ Pijarzy } \\
\hline 41. & $\begin{array}{l}\text { Wołyń: [Dąbrowica } \\
\text { i Międzyrzec Korecki] }\end{array}$ & $\begin{array}{l}1800,1805 \\
1800,1804\end{array}$ & DAŻO & F. 90, op. 1 , spr. $213 b$ \\
\hline \multirow{4}{*}{42.} & \multirow{4}{*}{ Dąbrowica } & 1807 & DAŻO & F. 90 , op. 1 , spr. 251 \\
\hline & & 1818 & DAŻO & F. 90 , op. 1 , spr. 320 \\
\hline & & 1820 & DAŻO & F. 90 , op. 1 , spr. 429 \\
\hline & & $1822-1831$ & DAŻO & $\begin{array}{l}\text { F. 90, op. 1, spr. 479; 531; } \\
579 ; 634 ; 684 ; 736 ; 790 ; \\
842 ; 892 ; 979\end{array}$ \\
\hline \multirow{7}{*}{43.} & \multirow{7}{*}{ Międzyrzec Korecki } & 1804 & DAŻO & F. 90 , op. 1 , spr. 240 \\
\hline & & $1818-1820$ & DAŻO & $\begin{array}{l}\text { F. } 90, \text { op. } 1 \text {, spr. } 342-343 ; \\
397 ; 449\end{array}$ \\
\hline & & $1822-1825$ & DAŻO & $\begin{array}{l}\text { F. } 90, \text { op. } 1 \text {, spr. } 501 ; 553 ; \\
601 ; 654\end{array}$ \\
\hline & & $1827-1833$ & DAŻO & $\begin{array}{l}\text { F. } 90 \text {, op. } 1 \text {, spr. } 760 ; 812 \text {; } \\
863 ; 965 ; 1017 ; 1058\end{array}$ \\
\hline & & 1839 & DAŻO & F. 90 , op. 1 , spr. 1078 \\
\hline & & $1841-1842$ & DAŻO & $\begin{array}{l}\text { F. 90, op. 1, spr. 1093; } \\
1110\end{array}$ \\
\hline & & 1850 & DAŻO & F. 90, op. 1, spr. 1156 \\
\hline \multicolumn{5}{|c|}{ Reformaci } \\
\hline 44. & \begin{tabular}{|l} 
Wołyń: \\
[Dederkały i Krzemieniec]
\end{tabular} & 1799,1805 & DAŻO & F. 90, op. 1 , spr. $213 b$ \\
\hline
\end{tabular}




\begin{tabular}{|c|c|c|c|c|}
\hline \multirow{8}{*}{45.} & \multirow{8}{*}{ Dederkały } & $1817-1819$ & DAŻO & $\begin{array}{l}\text { F. } 90 \text {, op. } 1 \text {, spr. } 297 ; 322 ; \\
375\end{array}$ \\
\hline & & $1822-1833$ & DAŻO & $\begin{array}{l}\text { F. 90, op. 1, spr. 480; 532; } \\
580 ; 631 ; 682 ; 738 ; 792 ; \\
840 ; 891 ; 945,956 ; 997 ; \\
1040\end{array}$ \\
\hline & & 1828 & CDIAU, Kijów & F. 2227 , op.1, spr. 671 \\
\hline & & 1839 & DAŻO & F. 90, op. 1 , spr. 1077 \\
\hline & & 1841 & DAŻO & F. 90 , op. 1, spr.1085 \\
\hline & & 1850 & DAŻO & F. 90 , op. 1 , spr. 1150 \\
\hline & & 1876 & DAŻO & $\begin{array}{l}\text { F. 90, op. 1, spr. 1283- } \\
1284\end{array}$ \\
\hline & & 1884 & DAŻO & F. 90 , op. 1 , spr. 1313 \\
\hline \multirow{4}{*}{46.} & \multirow{4}{*}{ Krzemieniec } & 1818 & DAŻO & F. 90 , op. 1 , spr. $334 \mathrm{a}$ \\
\hline & & 1820 & DAŻO & F. 90 , op. 1, spr. 437 \\
\hline & & 1824 & DAŻO & F. 90 , op. 1, spr. 592 \\
\hline & & 1828 & DAŻO & F. 90 , op. 1, spr. 796 \\
\hline 47. & Żorniszcze & $1817 ?$ & DAŻO & F. 90, op. 1, spr. 1137 \\
\hline \multicolumn{5}{|c|}{ Trynitarze } \\
\hline \multirow{2}{*}{48.} & \multirow{2}{*}{$\begin{array}{l}\text { Podole: [Brahiłów i Kamieniec Podol- } \\
\text { ski] }\end{array}$} & 1824 & DAChO & F. 685 , op. 4 , spr. 22 \\
\hline & & $1829-1830$ & DAChO & F. 685 , op. 4 , spr. 30 \\
\hline 49. & $\begin{array}{l}\text { Wołyń: [Beresteczko, Łuck, Szumbar, } \\
\text { Teofipol] }\end{array}$ & 1799 & DAŻO & F. 90 , op. 1 , spr. 227 \\
\hline \multirow{5}{*}{50.} & \multirow{5}{*}{ Beresteczko } & 1799 & DAŻO & F. 90 , op. 1, spr. 202 \\
\hline & & 1816 & DAŻO & F. 90 , op. 1, spr. 286 \\
\hline & & $1819-1820$ & DAŻO & F. 90 , op. 1 , spr. $366 ; 419$ \\
\hline & & 1822 & DAŻO & F. 90 , op. 1 , spr. 472 \\
\hline & & $1829-1830$ & DAŻO & F. 90 , op. 1 , spr. $831 ; 885$ \\
\hline \multirow{4}{*}{51.} & \multirow{4}{*}{ Łuck } & 1816 & DAŻO & F. 90 , op. 1, spr. 293 \\
\hline & & 1819 & DAŻO & F. 90 , op. 1 , spr. 412 \\
\hline & & $1822-1830$ & DAŻO & $\begin{array}{l}\text { F. 90, op. 1, spr. 516; 567; } \\
616 ; 649 ; 701 ; 756 ; 826 ; \\
859 ; 931\end{array}$ \\
\hline & & $1832-1833$ & DAŻO & $\begin{array}{l}\text { F. 90, op. 1, spr. 1012; } \\
1071\end{array}$ \\
\hline 52. & Szumbar & 1799 & DAŻO & F. 90, op. 1 , spr. 225 \\
\hline \multicolumn{5}{|c|}{ Klasztory żeńskie } \\
\hline \multirow{5}{*}{53.} & \multirow{5}{*}{ Brygidki: Łuck } & 1818-1819 & DAŻO & F. 90 , op. 1 , spr. $341 ; 395$ \\
\hline & & $1822-1823$ & DAŻO & F. 90 , op. 1 , spr. $500 ; 548$ \\
\hline & & $1825-1828$ & DAŻO & $\begin{array}{l}\text { F. } 90 \text {, op. 1, spr. } 651 ; 699 ; \\
753 ; 808\end{array}$ \\
\hline & & $1830-1831$ & DAŻO & F. 90 , op. 1 , spr. 909; 964 \\
\hline & & 1833 & DAŻO & F. 90 , op. 1 , spr. 1055 \\
\hline 54. & $\begin{array}{l}\text { Dominikanki: } \\
\text { Kamieniec Podolski }\end{array}$ & $\begin{array}{l}1824 \\
1825\end{array}$ & DAChO & $\begin{array}{l}\text { F. } 685 \text {, op. } 4 \text {, spr. } 21 ; \\
\text { op. } 2 \text {, spr. } 2\end{array}$ \\
\hline \multirow[b]{2}{*}{55.} & \multirow[b]{2}{*}{ Karmelitanki: Dubno } & 1819 & DAŻO & F. 90, op. 1, spr. 381 \\
\hline & & 1881 & DAŻO & $\begin{array}{l}\text { F. 90, op. 1, spr. 1302- } \\
1303\end{array}$ \\
\hline
\end{tabular}




\begin{tabular}{|c|l|c|l|l|}
\hline \multirow{2}{*}{56.} & Szarytki: Żytomierz & 1799 & DAŻO & F. 90, op. 1, spr. 213b; \\
& Gródek Podolski & 1825 & DAChO & F. 685, op. 2, spr. 2 \\
\hline 57. & Wizytki: Kamieniec Podolski & 1844 & DAChO & F. 689, op. 1, spr. 81 \\
\hline \multicolumn{2}{|c|}{ Ogółem: } & $\mathbf{1 7 9 2 - 1 8 8 4}$ & & 387 Poszytów \\
\hline
\end{tabular}

\title{
VISITATION RECORDS OF THE DIOCESE OF KAMYANYETS AND LUTSK-ZHYTO- MYR AND (THE END OF THE 18TH CENTURY - THE BEGINNING OF THE $20^{\mathrm{TH}}$ CENTURY) IN THE COLLECTIONS OF UKRAINIAN ARCHIVES
}

\begin{abstract}
Summary
Visitations are one of the most valuable and interesting church sources. This article attempts to present the condition of visitation records of churches and monasteries of the Diocese of Lutsk-Zhytomyr and Kamyanyets from the late 18th to the early 20th century in the archives of Ukraine. Difficult history of these lands in the last century contributed to a considerable dispersal of interesting materials, and what is worse, to irreversible destruction of some of the records. Currently, the largest number of the visitation descriptions of the mentioned dioceses are preserved in the Central State of Historical Archive of Ukraine in Kyiv and the State Archive of Zhytomir and Khmelnytskyi Oblast, which include, among others, the fonds of the Roman-Catholic Consistory of Kamyanyets and Lutsk-Zhytomyr and the visitation records of the monasteries in the Diocese of Lutsk-Zhytomyr. The presented material showed that the oldest of the surviving visitation records of the churches and monasteries in Podolia, Volhynia and the Kiev region come from the mid-90s of the 18th century and the latest ones come from 1909.
\end{abstract}

